\title{
Garnitury okuć rzemieni i inne elementy ozdobne wielkomorawskich mieczy*
}

Sword-belt Sets and other Decorations of the Great Moravian Swords

\begin{abstract}
Abstrakt: Tematem artykułu jest rekonstrukcja wyglądu pochwy miecza wielkomorawskich wojowników. Autor skupia się w nim przede wszystkim na garniturach okuć rzemieni i pasów służących do przypinania miecza, ale nie pomija także innych ozdobnych elementów pochwy miecza, jakie stosowano na obszarze Wielkich Moraw w Ix i na początku x w. Artykuł prezentuje głównie analizę składu garniturów mieczowych znanych z obszarów Wielkich Moraw w kontekście szerszej typologii i zagadnień chronologicznych znalezisk z obszaru
\end{abstract}

Europy znajdującego się pod wpływem kultury karolińskiej między początkiem Ix a pierwszą połową X w.

Rozbudowane garnitury mieczowe stały się bardzo popularne na Wielkich Morawach w drugiej połowie IX w. Wtedy też zanikają miecze ze zdobionymi głowicami $(\mathrm{B} / \mathrm{H}, \mathrm{K})$, a pojawiają się modele $\mathrm{z}$ głowicami niezdobionymi (N/X, Y). Możliwe zatem, że popularyzacja garniturów mieczowych wśród wielkomorawskich wojowników nastąpiła w odpowiedzi na konieczność stosowania mniej okazałej broni.

Słowa kluczowe: wczesne średniowiecze, kultura karolińska, Wielkie Morawy, miecz, pochwa miecza, okucia rzemieni

Tematem tego artykułu jest rekonstrukcja wyglądu pochwy miecza wielkomorawskich wojowników. Skupiam się w nim przede wszystkim na garniturach okuć rzemieni i pasów służących do przypinania miecza, ale nie pomijam także innych ozdobnych elementów pochwy, jakie stosowano na obszarze Wielkich Moraw w IX i na początku X w. Artykuł prezentuje głównie analizę składu garniturów mieczowych znanych z obszarów Wielkich Moraw w kontekście szerszej typologii i zagadnień chronologicznych znalezisk z obszaru Europy znajdującego się pod wpływem kultury karolińskiej między początkiem IX a pierwszą połową $\mathrm{X}$ w. Istota badań nad metalowymi elementami garniturów mieczowych i pochew mieczy spoczywa przede wszystkim w przydatności okuć rzemieni (podobnie jak zresztą wielu innych zabytków metalowych) w określaniu chronologii zespołów, jako

* Artykuł powstał w ramach projektów badawczych (I:I): APVV-19-0563 „Mocenské centra a ich zázemie v 8.-II. storočí" i VEGA 2/OI24/20 „Ekonomika stredoveku (6.-I3. storočie)”. 
tzw. niezależnych wyznaczników i to o wiele lepszych niż sama broń (Robak 2013). Mieczowe pasy w kontynentalnej Europie przeżywały bowiem od schyłku viII w. do początku X w. prawdziwy rozkwit artystyczny, powiązany z rozkwitem kultury i sztuki tzw. Renesansu Karolińskiego. W przeciwieństwie do mieczy, elementy ozdobne były bardziej czułe na zmiany stylistyczne wypływające z trendów estetycznych oraz aktualnie panującej mody. W ciągu relatywnie krótkiego czasu przeszły też wiele zmian technologicznych dotyczących sposobu ich funkcjonowania w praktyce. Mogą zatem stanowić dobrą podstawę do określania chronologii zespołów zwartych i stanowisk i budowania ogólnych systemów chronologicznych.

Tematyka samych mieczy okresu karolińskiego w Europie i wikińskiego w Skandynawii i w basenie Morza Bałtyckiego jest analizowana na gruncie archeologii i bronioznawstwa od stu lat, od kiedy J. Petersen (1919) wydał swą pionierską pracę De norske vikingesverd, w której stworzył prostą i stosowaną do dzisiaj typologię opartą na zróżnicowaniu technologicznym i stylistycznym rękojeści. Od tego czasu powstało wiele opracowań, zarówno monotematycznych, poświęconych wyłącznie mieczom, lub też traktujących szerzej o wczesnośredniowiecznym uzbrojeniu w ogóle ${ }^{1}$. Na gruncie polskiej szkoły bronioznawstwa średniowiecznego podwaliny pod te badania położyły prace M. Sarnowskiej i A. Nadolskiego, kontynuowane następnie przez M. Głoska. O ile jednak mieczom wczesnośredniowiecznym, zwłaszcza karolińskim, światowa archeologia poświęciła i nadal poświęca ogromną uwagę, o tyle zagadnienie „otoczenia” miecza jest w zasadzie bardziej wykorzystywane przez amatorskich i profesjonalnych rekonstruktorów, którzy czynią to do pewnego stopnia w ramach własnych zainteresowań, aniżeli przez badaczy-archeologów. W porównaniu do liczby publikacji dotyczących samych mieczy, publikacje poświęcone wczesnośredniowiecznym pasom służącym do przypinania miecza stanowią niewielki ich ułamek, a często bywają zaledwie dodatkowym rozdziałem w pracach monograficznych. Uwaga badaczy jest zresztą nakierowana na artystyczną stronę przedmiotów, podczas gdy zagadnienia typologiczne i technologiczne są zwykle pomijane. Świadczą o tym zresztą niespójne nazewnictwo poszczególnych elementów pasów mieczowych (i to we wszystkich językach) oraz niekiedy sprzeczne koncepcje zastosowania poszczególnych elementów. Częściową przyczyną tego stanu rzeczy może być znacznie rozproszona, a przy tym liczebnie ograniczona (np. w porównaniu do zabytków okresu merowińskiego lub kultury Skandynawii okresu wikińskiego) baza źródłowa oraz brak opracowań zbiorczych. Wśród nielicznych prac poświęconych zagadnieniom typologiczno-chronologicznym garniturów mieczowych okresu karolińskiego wspomnieć

1 Wyczerpujący przegląd stanu badań na rok 2004 przedstawił L. Marek (2004).Z istotnych nowych zbiorczych ujęć monotematycznych należy przytoczyć prace F. Androŝuka (20II) oraz J. Hoška, J. Košty i P.Žákovskiego (2019). 
należy przede wszystkim opracowania E. Wamersa (1981; 1985; 1994; 2008; 2011; Die Macht... 2005) oraz M. Baumeistera (1998), które jednakże bazowały głównie na znaleziskach zachodnioeuropejskich i importach karolińskich w Skandynawii.

W polskiej literaturze prace K. Wachowskiego, poświęcone głównie wielkomorawskim militariom (1986-1987; 1992), wskazywały na ogromny wpływ kultury karolińskiej na kształtowanie się kultury Wielkich Moraw, zwłaszcza w kwestii ubioru i wyposażenia wojowników. Niestety, przyrost informacji uzyskiwanych na podstawie badań archeologicznych i ewolucja wiedzy na temat chronologii dziejów Słowiańszczyzny sprawiają, że część tez i propozycji prezentowanych w tych opracowaniach jest już nieaktualna. Tym niemniej, badania te wskazały kierunek umożliwiający podjęcie prac nad powiązaniem części zabytków łączonych z kulturą wielkomorawską $\mathrm{z}$ obszarem analiz zabytków karolińskich.

W ostatnich latach badania nad tym zagadnieniem podją Š. Ungerman (20ı1a; 20IIb; 20I7), który od początku wskazywał na niedostatki starszych badań i potrzebę ich rewizji na bazie krytyki źródeł. Tematyce ozdób pasa w okresie karolińskim i wpływom karolińskim na obszary Słowiańszczyzny poświęcona została także monografia (Robak 20I3; 20I4). Wnioski płynące z tych badań są podobne - znaczną część kultury materialnej Wielkich Moraw, zwłaszcza z zakresu militariów, można analizować w kontekście kultury karolińskiej i traktować jako jej peryferyjny i specyficzny wariant, w dużym jednak stopniu paralelny z głównym (zachodnioeuropejskim) nurtem. Tym samym pojęcia „karoliński” i „wielkomorawski” w kontekście militariów nabierają niekiedy wymiennego znaczenia, w zależności, czy odnoszą się do kontekstu kulturowego, czy też typologicznego. Stąd też uzasadnione jest określanie wielkomorawskich garniturów mieczowych i ogólnie dużej części uzbrojenia i wyposażenia wielkomorawskiego wojownika mianem „karolińskiego” lub „w typie karolińskim”.

\section{Tło historyczno-kulturowe}

Przegrana Awarów w wojnie z Frankami (788-803) i w konsekwencji upadek polityczny i rozkład społeczny i kulturowy kaganatu awarskiego, skutkowały zmianą układów politycznych i sił w rejonie dorzecza środkowego Dunaju. Otworzyły

2 Określenia „wielkomorawski” w tym kontekście używam wyłącznie jako określenia kultury materialnej charakterystycznej dla Słowian zamieszkujących obszary dzisiejszych Moraw i Słowacji pomiędzy przełomem pierwszej i drugiej ćwierci IX w. a pierwszą połową X w. Mam świadomość niefortunności tej nazwy wyprowadzonej od historycznego pojęcia Wielkich Moraw, oznaczającego konkretny organizm polityczny, którego czas istnienia i obszar niekoniecznie pokrywał się z czasem archeologicznym i obszarem przypisywanym kulturze materialnej. 
też przed Imperium Karolińskim możliwość wzmożenia aktywności politycznej, której celem było polityczne zagospodarowanie, trwalsze związanie z imperium Franków i kontrola słowiańskich sąsiadów „uwolnionych” od Awarów (Třeštík 2009). Polityczna i kulturowa ekspansja frankijska, połączona z szerzeniem chrześcijaństwa, wywarła wpływ nie tylko na sytuację polityczną regionu, ale także na kulturę materialną, społeczną i symboliczną poszczególnych społeczności, które, jeśli tylko nie stawiały oporu, dość szybko starano się zintegrować z centrum. Dla Imperium Karolińskiego była to znakomita okazja do poszerzania swoich wpływów i uczynienia granic bezpieczniejszymi, dla lokalnych plemion obietnica korzyści politycznych, gospodarczych i społecznych.

Wpływy kultury karolińskiej na obszarze północnej części dorzecza środkowego Dunaju obserwujemy od przełomu VIII i IX w. (Robak 2013: 19I-202, 207-2I2; 2017-2018: 33I-334), należy jednak podkreślić, że przynajmniej do drugiej dekady IX w. były to wpływy nieznaczne, incydentalne, związane głównie z działaniami wojennymi prowadzonymi w tym rejonie Europy w związku z wojnami awarskimi. Skutkowały jednak zaszczepieniem pewnego rodzaju „karolińskiej mody militarnej”, której ślady są wyraźne w materiale archeologicznym mniej więcej od lat 20. IX w. Wtedy na Morawach, ale i na terenie zachodniej Słowacji zaczynają się pojawiać nowe typy zachodnioeuropejskiego uzbrojenia (ostrogi, miecze) i elementy stroju (głównie komplety okuć rzemieni) charakterystyczne dotąd dla kultur plemion tworzących społeczność Imperium Karolińskiego (Robak 2018a). Nowsze badania (Robak 2013: 197-202, 207-209; 2017-2018) i datowanie metodami archeologicznymi wskazują wyraźnie, że początek fali importów karolińskich na wspomniane obszary koreluje z pojawieniem się ludu Morawian w źródłach historycznych jako sprzymierzeńca Cesarstwa $(822$ r.) oraz z przyjęciem przez nich chrześcijaństwa $(831$ r.). Nie, jak dawniej uważano, z początkiem wojen awarskich (790 r.). Należy zatem przypuszczać, że to głównie nawiązanie kontaktów dyplomatycznych z Cesarstwem i ogólna reorientacja polityczna Morawian „na zachód” skutkowaly przejmowaniem zwyczajów i elementów ubioru karolińskiej szlachty przez ich morawskich odpowiedników (podobnie jak to się działo w południowej Panonii i Dalmacji oraz w Kotlinie Czeskiej). Fenomen adaptacji karolińskiego sposobu demonstracji pozycji społecznej poprzez elementy ubioru mógł wynikać zarówno z politycznej konieczności, jak i aspiracji morawskich elit do stania się częścią karolińskiego świata. A ponieważ elity każdej społeczności zawsze stanowiły wzorce do naśladowania, atrakcyjna, także wizualnie, elitarna kultura karolińska stała się inspiracją i wyzwaniem kulturowym dla elit czeskich i morawskich, które zapewne nie chciały być dłużej postrzegane jako barbarzyńcy, zwłaszcza przez swoich karolińskich partnerów. Uczestniczenie w tej kulturowej grze było możliwe tylko poprzez akceptację pewnych wzorców zachowań, elementów stroju, 
symbolicznych gestów, wymiany darów potwierdzających, że stanowią integralną część ówczesnego chrześcijańskiego świata, definiowanego przez karolińskie elity. Fakt bardzo szybkiego przyjęcia chrześcijaństwa przez Morawian, liczne prywatne relacje wielkomorawskich i bawarskich elit i uczestnictwo władców i elit wielkomorawskich w polityce regionalnej, a nawet europejskiej, świadczą o spełnieniu tych aspiracji i dość szybkiej integracji najwyższych warstw społeczeństwa z ich frankijskimi odpowiednikami.

\section{Baza źródłowa}

Garnitury mieczowe stosowane na terenie Wielkich Moraw ${ }^{3}$ były bądź importami z zachodu Europy, bądź też lokalnymi naśladownictwami czy wariacjami zachodnioeuropejskich garniturów karolińskich, co dość łatwo stwierdzić poprzez choćby pobieżne porównanie typów okuć, które zawierały. Jednak musimy pamiętać, że w przeciwieństwie do licznych zachowanych garniturów późnomerowińskich, pochodzących ze znalezisk grobowych i umożliwiających dość precyzyjną rekonstrukcję wyglądu i sposobu zawieszenia (Menghin 1983; Baumeister 1998: 163-170; Lüppes 2010), garnitury mieczowe epoki Karolingów zachowały się w większości jako zdekompletowane zestawy (w nielicznych pochówkach i skarbach) lub pojedyncze przedmioty, wyrwane ze swojego pierwotnego kontekstu albo pozbawione pierwotnej funkcji (np. okucia przerobione na zawieszki czy zapinki). Uniemożliwia to pełną rekonstrukcję sposobu noszenia miecza w tym okresie i skazuje badaczy na niekiedy daleko posunięte teoretyzowanie. $\mathrm{O}$ ile przy tym wygląd karolińskich garniturów mieczowych stosowanych na zachodzie Europy może być do pewnego stopnia rekonstruowany na podstawie porównania zachowanych znalezisk z iluminacjami rękopisów, o tyle w przypadku garniturów wielkomorawskich nie dysponujemy żadnymi źródłami ikonograficznymi. Problematyczny dla badań jest także stan zachowania źródeł archeologicznych. W rzeczywistości nie jest bowiem znany ani jeden wielkomorawski garnitur okuć rzemieni miecza, o którym można by z pewnością stwierdzić, że jest kompletny i zachowany w stanie umożliwiającym stuprocentowe rozpoznanie poszczególnych elementów. Zachowało się natomiast sporo elementów stanowiących części składowe. W przypadku tych znalezisk elementów garniturów mieczowych, które stanowiły importy z zachodu Europy lub też były ich kopiami, identyfikacja była możliwa poprzez proste odniesienie się do oryginałów. W przypadku garniturów

з Na potrzeby opracowania zaliczam tu także zespoły pochodzące z obszaru Kotliny Czeskiej, która choć nie stanowiła obszaru macierzystego Wielkich Moraw, była mu wówczas kulturowo bliska i politycznie z nim związana i w niemal identycznym stopniu podlegała wpływom kulturowym i politycznym Karolingów. 
występujących tylko na obszarze Europy Środkowej, głównie Moraw i Słowacji, wyznaczenie typów wymagało porównania składu wielu znalezisk zdekompletowanych garniturów i jest do pewnego stopnia hipotetyczne.

Aby zobrazować skalę trudności, warto zauważyć, że obecnie znamy około setki mieczy związanych z zespołami przypisywanymi kulturze wielkomorawskiej lub datowanych na ten okres, z czego około dwie trzecie pochodzi z grobów ${ }^{4}$. Większość mieczy znalezionych w grobach miała częściowo zachowaną drewnianą pochwę, niekiedy ze śladami nitów czy innych metalowych elementów ozdobnych. Jednak zaledwie jedenaście zespołów zawierało czasem mocno zniszczone garnitury mieczowe, a dziesięć dalszych zestawy kilku okuć rzemieni nie tworzących konkretnego typu garnituru, ale po prostu zdobiących pas (tabela I). Oprócz tego znanych jest kilkadziesiąt elementów pochodzących spoza zespołów grobowych, stanowiących różne ozdobne części rzemieni służących do przypinania miecza (Robak 2013). Na podstawie ich analiz można podjąć próby rekonstrukcji wyglądu i sposobu funkcjonowania wielkomorawskich garniturów mieczowych oraz generalnie wyglądu miecza.

W tworzeniu typologii, zwłaszcza w określaniu hipotetycznej funkcji niektórych okuć, pomocne były także ogólne informacje dotyczące sposobu noszenia miecza we wczesnym średniowieczu. Miecz noszony na pasie opasującym biodra lub talię mocowany był górną częścią pochwy do rzemienia głównego. Stanowił go pas wykonany ze skóry lub innych materiałów organicznych i spinany sprzączką lub klamrą, względnie wiązany na węzeł. Rzemień główny mógł być mocowany do pochwy miecza za pomocą dodatkowych elementów (okuć, żeberka) lub tylko tworzyć pętlę. Ze względu na długość miecza i wygodę w jego wydobywaniu, pochwa nie powinna była być zawieszana pionowo tylko w jednym punkcie, ale pozostawać w nachyleniu. Nachylenie to, warunkowane w zależności od upodobań, mogło wynosić od $30^{\circ}$ do $70^{\circ}$ względem osi ciała noszącego. Do utrzymywania miecza w nachyleniu służył drugi rzemień, obejmujący pochwę miecza poniżej górnego mocowania i łączący się drugim końcem z rzemieniem głównym. Rzemień dolny, ze względu na swą funkcję, powinien posiadać możliwość regulacji długości. W przypadku miecza noszonego na pasie przechodzącym przez ramię, rzemień dolny nie był niezbędny. Jak jednak można wnioskować z zachowanej

4 Oszacowano na podstawie: Hošek i in. 2019b; Ruttkay 1976; Hanuliak 2004 oraz kwerendy własnej. Szacunki przybliżone wynikają z niepewnych i niekiedy sprzecznych informacji. Wielkomorawskie miecze ze Słowacji wymagają podjęcia nowych studiów technologicznych i porównawczych, analizy danych źródłowych (część zabytków nie była krytycznie opublikowana) oraz przewartościowania chronologii zespołów. Widoczna jest jednak różnica pomiędzy terenem Słowacji i Moraw. Ze Słowacji pochodzi zaledwie jeden pochówek z garniturem mieczowym (Závada, okr. Topolčany) i osiem w miarę pewnych (tzn. odkrytych lub zadokumentowanych przez archeologów) pochówków z mieczem. 
Tab.1. Zespoły grobowe zawierające miecz lub sax i różne elementy ozdobne pasa i/lub pochwy. Znak + oznacza obecność okuć, które nie tworzyły konkretnego typu garnituru lub nie jest on możliwy do identyfikacji.

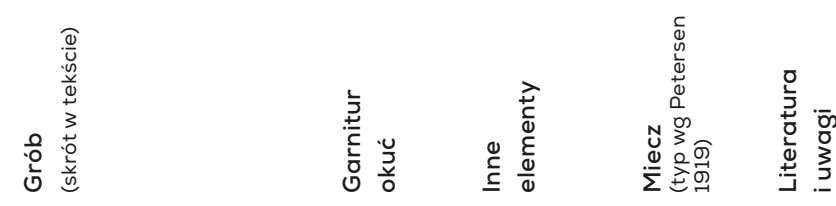

\begin{tabular}{llll}
\hline $\begin{array}{l}\text { Břeclav-Pohansko/CZ, } \\
\text { gr. I74 (BP-I74) }\end{array}$ & $\begin{array}{l}\text { żelazne } \\
\text { żeberko } \\
\text { pochwy } \\
\text { miecza }\end{array}$ & Kalousek I97I: III-II2; \\
& & Košta i in. 20I9 \\
& &
\end{tabular}

\begin{tabular}{|c|c|c|c|c|}
\hline $\begin{array}{l}\text { Břeclav-Pohansko/Cz, } \\
\text { gr. } 257(\mathrm{BP}-257)\end{array}$ & + & & $\mathrm{N} / \mathrm{X}$ & $\begin{array}{l}\text { Kalousek I97I: I50-I5I; } \\
\text { Košta i in. } 2019\end{array}$ \\
\hline Dobšice/cz & & $\begin{array}{l}\text { pierścień } \\
\text { mocujący } \\
\text { rzemień }\end{array}$ & $\mathrm{x}$ & $\begin{array}{l}\text { Hošek i in. } \\
\text { 2019b: } 99-100\end{array}$ \\
\hline Jarohněvíce/Cz & $\begin{array}{l}\text { typ I } \\
\text { lub II (?) }\end{array}$ & & $\mathrm{x}$ & $\begin{array}{l}\text { Dostál 1966: 130-131 } \\
\text { Przedmioty zaginęty. }\end{array}$ \\
\hline Kolín/Cz & typ I & & $\begin{array}{l}\mathrm{nn} \\
(\mathrm{K} / \mathrm{H} / \mathrm{X} ?)\end{array}$ & $\begin{array}{l}\text { Lutovský 1994; } \\
\text { Košta, Lutovský } 2014\end{array}$ \\
\hline
\end{tabular}

$\begin{array}{lll}\begin{array}{l}\text { Kostice-Zadní hrud/CZ, typ IV } \\ \text { gr. } 3(\mathrm{KZ}-3)\end{array} & \mathrm{N} & \text { Balcárková i in. 2017: 342; } \\ & & \text { Košta i in. 2019 } \\ & & \text { Garnitur nieopublikowany, } \\ & & \begin{array}{l}\text { znany tylko z lakonicznego } \\ \text { opisu. }\end{array}\end{array}$

\begin{tabular}{|c|c|c|c|}
\hline $\begin{array}{l}\text { Mikulčice/CZ, } \\
\text { gr. 265/II }(M-265)\end{array}$ & + & $\mathrm{H}$ & $\begin{array}{l}\text { Košta 2005: 160; } \\
\text { 2008: przyp. } 7\end{array}$ \\
\hline $\begin{array}{l}\text { Mikulčice/CZ, } \\
\text { gr. 375/III (M-375) }\end{array}$ & typ II & $\mathrm{x}$ & $\begin{array}{l}\text { Ungerman 2011a: } 58 \mathrm{I}, \mathrm{Abb} .6 \text {; } \\
\text { Klanica i in. 2019: } 54-55\end{array}$ \\
\hline $\begin{array}{l}\text { Mikulčice/CZ } \\
\text { gr. 500/III (M-500) }\end{array}$ & typ I (?) & $\mathrm{x}$ & $\begin{array}{l}\text { Ungerman 2011a: } 58 \mathrm{I}-582 \text {, } \\
\text { Abb. } 7 \text {; } \\
\text { Klanica i in. 2019: } 91-93\end{array}$ \\
\hline $\begin{array}{l}\text { Mikulčice/Cz } \\
\text { gr. } 580 / \mathrm{III}(\mathrm{M}-580)\end{array}$ & + & $\begin{array}{l}\mathrm{nn} \\
\text { sax }\end{array}$ & $\begin{array}{l}\text { Košta, Hošek 2008a; } \\
\text { Velká Morava... 20I4: nr I8I; } \\
\text { Klanica i in. 2019: II7-I20 }\end{array}$ \\
\hline $\begin{array}{l}\text { Mikulčice/CZ, } \\
\text { gr. } 1347(M-1347)\end{array}$ & + & $\mathrm{x}$ & Klanica I985: 513 \\
\hline
\end{tabular}


Tab.1. (cd).

\begin{tabular}{|c|c|c|c|c|}
\hline 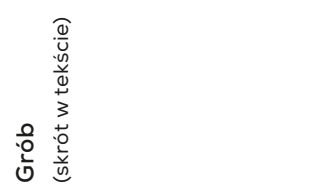 & $\begin{array}{l}\frac{1}{2} \\
\frac{H}{c} \\
\frac{1}{0} \\
0 \\
0\end{array}$ & 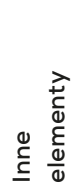 & 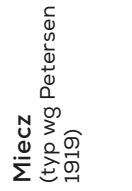 & 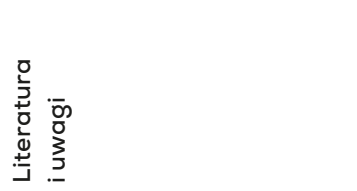 \\
\hline $\begin{array}{l}\text { Mikulčice/CZ, } \\
\text { gr. } 1665 \text { (M-1665) }\end{array}$ & + & & $\mathrm{x}$ & Klanica $1987: 36$, tab. $6: 6-7$ \\
\hline $\begin{array}{l}\text { Nechvalín 2/CZ, } \\
\text { gr. } 139(\mathrm{~N}-139)\end{array}$ & + & & $\operatorname{sax}$ & Klanica 2006: 20: 139 \\
\hline $\begin{array}{l}\text { Nechvalín/cz, } \\
\text { gr. } 126(\mathrm{~N}-\mathrm{I} 26)\end{array}$ & + & & $\mathrm{x}$ & Klanica 2006: tab. I8 \\
\hline $\begin{array}{l}\text { Prušánky/Cz, } \\
\text { gr. } 229(\mathrm{P}-229)\end{array}$ & $\begin{array}{l}\text { typ I } \\
\text { lub II }\end{array}$ & & + & Klanica 2006: tab. 53: 229 \\
\hline $\begin{array}{l}\text { Rajhradice/cz, } \\
\text { gr. } 316(\mathrm{R}-316)\end{array}$ & typ V & & + & Staňa 2006: obr. 67: 316 \\
\hline $\begin{array}{l}\text { Rajhradice/CZ, } \\
\text { gr. 7I }(\mathrm{R}-7 \mathrm{I})\end{array}$ & typ IV & & $\mathrm{Y}$ & $\begin{array}{l}\text { Staňa 2006: obr. 54: } \\
\text { Šolle 7I }\end{array}$ \\
\hline $\begin{array}{l}\text { Šlapanice/cz, } \\
\text { gr. Io }\end{array}$ & + & & $\begin{array}{l}\text { specjalny } \\
2\end{array}$ & $\begin{array}{l}\text { Geisler 2010; Geisler 2013: } \\
\text { I34-135, I39-140; } \\
\text { Hošek i in. 2019b: 25I-252 } \\
\text { Garnitur niepublikowany, } \\
\text { skład niemożliwy } \\
\text { do określenia. }\end{array}$ \\
\hline $\begin{array}{l}\text { Šlapanice/CZ, } \\
\text { gr. } 29\end{array}$ & + & & $\mathrm{x}$ & $\begin{array}{l}\text { Hošek i in. 2019b: } 252-253 \\
\text { Garnitur niepublikowany, } \\
\text { prawdopodobnie typ I lub II. }\end{array}$ \\
\hline $\begin{array}{l}\text { Stará Kouřim/cz, } \\
\text { gr. } 55(\mathrm{sK}-55)\end{array}$ & typ I & & $\mathrm{nn}$ & Šolle 1966: 260 \\
\hline $\begin{array}{l}\text { Staré Město/CZ, } \\
\text { gr. } 190 / 50(\mathrm{SM}-190 / 50)\end{array}$ & + & & $\mathrm{x}$ & $\begin{array}{l}\text { Hrubý 1955: 491-492; Velká } \\
\text { Morava... 2014: nr I85, I87; } \\
\text { Hošek i in. 2019a }\end{array}$ \\
\hline $\begin{array}{l}\text { Staré Město/CZ, } \\
\text { gr. 223/5I (SM-223/5I) }\end{array}$ & + & & $\mathrm{H}$ & $\begin{array}{l}\text { Hrubý 1955: 524-525; } \\
\text { Kouřil 2005: Abb. 9: 3; Velká } \\
\text { Morava... 2014: nr 192, } 193\end{array}$ \\
\hline $\begin{array}{l}\text { Závada/sK, } \\
\text { gr. } 23(z-23)\end{array}$ & typ v & & $\mathrm{x}$ & $\begin{array}{l}\text { Bialeková 1982: 132-134, } \\
\text { I50-151, obr. I3, I4, I6; } \\
\text { Robak 2018b }\end{array}$ \\
\hline
\end{tabular}


ikonografii (Psatterz Stuttgarcki, Psatterz Utrechcki, Ztoty Psatterz i in.), w Europie epoki Karolingów ten sposób noszenia miecza nie był popularny. Stosowano go natomiast w armii bizantyńskiej (Kolias 1988: 137).

\section{Elementy garniturów mieczowych i pochew mieczy}

Analizy zespołów archeologicznych oraz luźnych znalezisk okuć rzemieni miecza z obszaru całej Europy (w sumie około 300 przedmiotów) pozwoliły na wydzielenie pięciu podstawowych typów karolińskich garniturów mieczowych (Robak 20I3; 2018b) stosowanych w okresie późnokarolińskim (początek IX w. - I. poł. X w.) na terenie objętym wpływami kultury karolińskiej (ryc. I). Na bazie tej analizy możliwe było także określenie chronologii oraz obszarów występowania poszczególnych typów garniturów mieczowych. Spośród pięciu zidentyfikowanych typów cztery występują na terenie dawnych Wielkich Moraw. Jedynym wyjątkiem okazał się typ III, charakterystyczny, jak dotąd, wyłącznie dla północno-zachodnich obszarów państwa karolińskiego.

\section{Typ I}

Garnitur okuć zawierający trójlistny rozdzielacz rzemieni, dwa okucia owalne i jedno okucie z przewleczką oraz wydłużone okucie końca rzemienia można śmiało nazywać „klasycznym” karolińskim (ryc. 2: A-D). Okucie trójlistne rozdzielało rzemienie na biodrze, dwa okucia owalne zdobiły rzemień w miejscu żeberka, a okucie z przewleczką pozwalało na regulację długości dolnego rzemienia pomocniczego (ryc. 2: G). Zestaw ten został przejęty wprost z zachodu Europy, gdzie w okresie późnokarolińskim (początek IX w. - początek X w.) stanowił najpopularniejszy i długo stosowany model garnituru mieczowego (w zasadzie od początku IX w., kiedy to powstają jego prototypy zdobione jeszcze we wczesnokarolińskim stylu, do ostatniej tercji IX w.). Elementy garnituru odnajdywane są na obszarze całej Europy objętej wpływami kultury karolińskiej, od Dalmacji po Wyspy Brytyjskie i Skandynawię. O jego popularności świadczą liczne znaleziska okuć trójlistnych (jest to chyba najliczniej odnajdowany element garniturów mieczowych) oraz duża różnorodność ich form (da się stwierdzić przynajmniej I2 sposobów mocowania do rzemieni) i stylistyki zdobienia, które pozwalają też na określanie chronologii znalezisk i śledzenie ich ewolucji stylistycznej (Robak 20I3: IO5-II3).

Rozwiązanie techniczne, które prezentował garnitur typu I, stanowiło wprost kontynuację modeli późnomerowińskich (Baumeister 1998: Abb. 4-6; Lüppes 2010) oraz wczesnokarolińskich (Robak 2013: 98-104) z trójkierunkowym rozdzielaczem rzemieni, a jego ewolucję można prześledzić na przykładach garnituru z Marquartstein w Bawarii (Helmbrecht 2008) oraz różnych znalezisk z terenów Chorwacji 


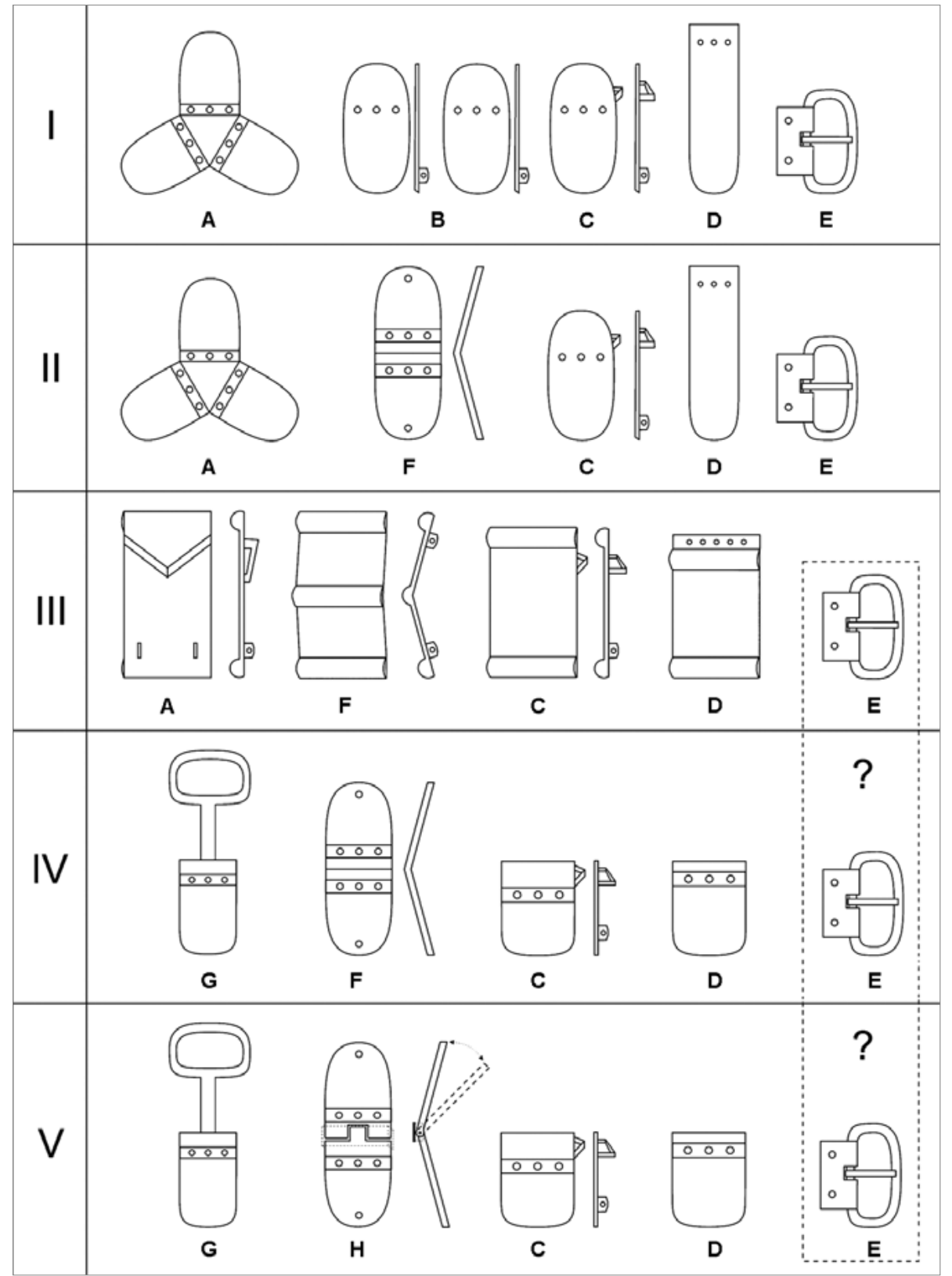

Ryc.1. Typologia garniturów mieczowych w typie karolińskim: A - trójkierunkowy rozdzielacz; B - okucie owalne; c - okucie z przewleczką; D - okucie końca głównego rzemienia; E - sprzączka; F - okucie dachowate; G - okucie z szyjką; H - okucie z zawiasem (rys. Z. Robak). 


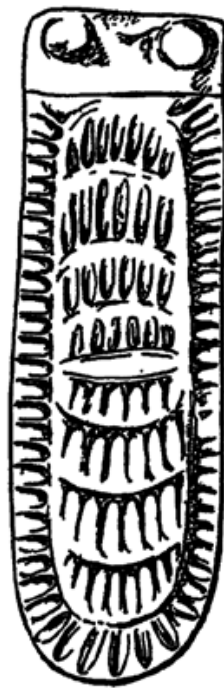

A

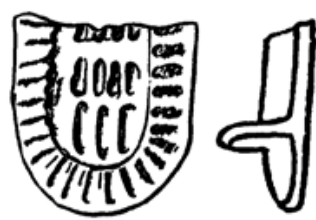

B

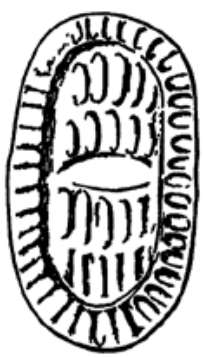

c
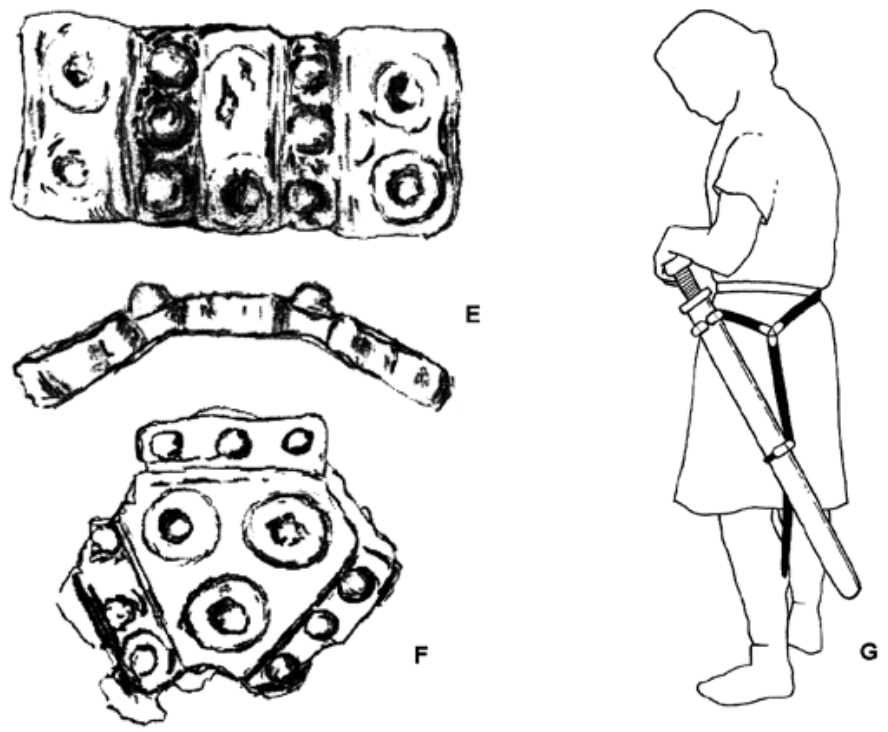

Ryc.2. Garnitur typu I - A-D: Stará Kouřim/Cz, gr. 55 (Šolle I966: 73). Brąz.

Garnitur typu II - E-F: Mikulčice/CZ, gr. 375 (Ungerman 20I7: obr. 7). Żelazo.

G: Sposób mocowania okuć w garniturach typu I oraz II (Košta, Hošek 20o8b: obr. 6). 
(Robak 2013: 143, I53). Choć gros znalezisk garniturów typu I i ich elementów pochodzi z obszarów Europy Zachodniej i Dalmacji, a także z Wysp Brytyjkkich i Skandynawii, gdzie dostawały się za pośrednictwem Wikingów, to pojedyncze znaleziska okuć trójlistnych i owalnych z terenów Moraw i zachodniej Słowacji świadczą, że garnitury typu I mogły być tu w okresie wielkomorawskim stosowane (ryc. 3). Potwierdzają to także dwa znaleziska grobowe z terenu Kotliny Czeskiej (sK-55 oraz grób z Kolína patrz tab. I), będące prawdopodobnie ceremonialnymi darami (oczywiście wraz z mieczami) dla jakichś czeskich książąt, zyskanymi w okresie zwiększonej aktywności politycznej państwa karolińskiego wobec Czechów (Wamers 1994: 32-42). Jako dary, w podobnych sytuacjach, elitarne garnitury mieczowe mogly zatem trafiać także do rąk przedstawicieli morawskich elit ${ }^{5}$. Nie jest natomiast tak oczywiste, czy garnitury z okuciem trójlistnym były na obszarze Wielkich Moraw produkowane przez lokalnych rzemieślników. Wszystkie znaleziska z tego obszaru bowiem znajdują swoje bliskie analogie stylistyczne i technologiczne wśród znalezisk karolińskich, brak natomiast pośród nich ewidentnych naśladownictw czy przedmiotów wykazujących zdecydowanie cechy stylu lokalnego.

\section{Typ II}

Drugi typ garnituru także zawierał okucie trójlistne i okucie z przewleczką oraz okucie końca rzemienia, ale dwa okucia owalne zastąpiono w nim jednym okuciem dachowatym (ryc. 2: F), które umieszczone było na górnym rzemieniu opasującym pochwę miecza w miejscu żeberka. Jego kształt kopiuje zresztą profil pochwy miecza. Jest to najbardziej enigmatyczny z garniturów, gdyż zachował się tylko $\mathrm{w}$ jednym zespole $(\mathrm{M}-375)$, a w pozostałych dwóch ( $\mathrm{P}-229$; Jarohněvíce) przedmioty były zbyt zniszczone, aby stwierdzić z całą pewnością, jaki tworzyły typ garnituru, choć II jest dość prawdopodobny.

Nie jest jasne, czy garnitur typu II został ,importowany” z zachodu Europy, czy też podobna kombinacja okuć wyewoluowała gdzieś na obszarze wschodnich peryferii Imperium Karolińskiego. Należy bowiem zauważyć, że wszystkie trzy znane zestawy pochodzą z obszaru Moraw, nie znamy natomiast żadnego

5 Słynne znaleziska z Blatnicy, okr. Martin/sk, w świetle najnowszych badań nad ich pochodzeniem, nie są w stanie się obronić jako zespół zwarty. Nie ma też jednoznacznych dowodów na to, że zabytki w ogóle pochodzą z okolic Blatnicy (Robak 2017). Najprawdopodobniej stanowiły część kolekcji osobliwości węgierskiego barona F. Révaya, właściciela zamków w Sklabinii i Blatnicy, pozyskanej w różnoraki, niemożliwy, w tym momencie, do prześledzenia sposób (Révayovie podróżowali po świecie i gromadzili wszelkie antyki). Karoliński garnitur mieczowy jest oczywiście kompletem, natomiast nie da się go w żaden sposób powiązać z wykazującym skandynawskie koneksje mieczem typu D i pozostatymi eksponatami. 

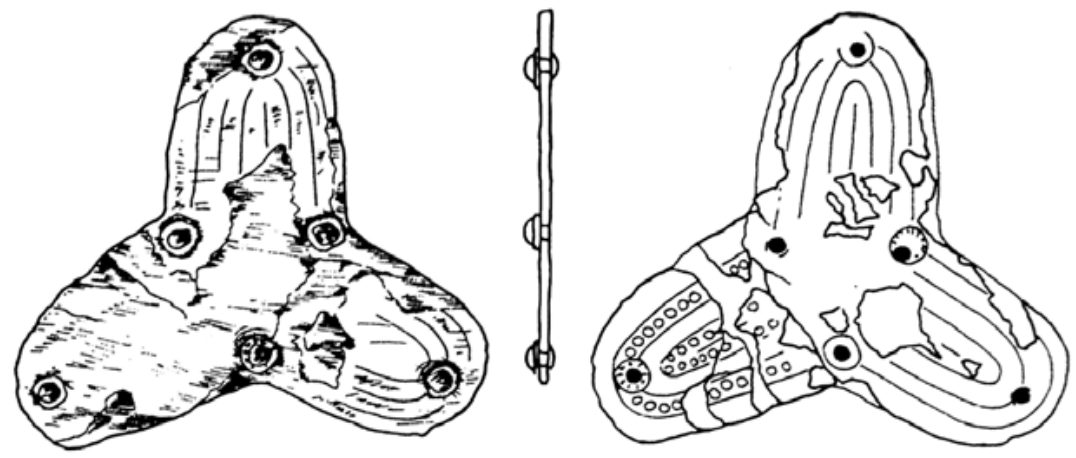

A
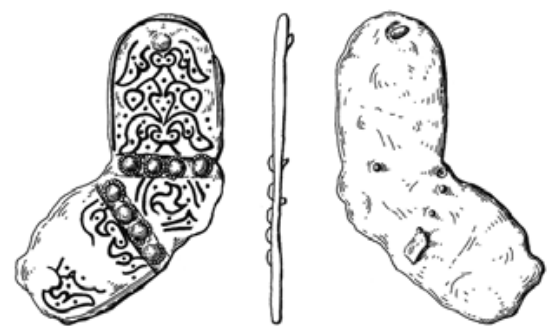

B

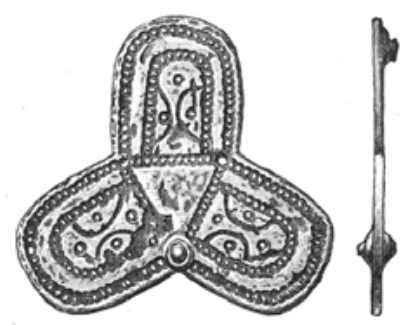

C $5 \mathrm{~cm}$
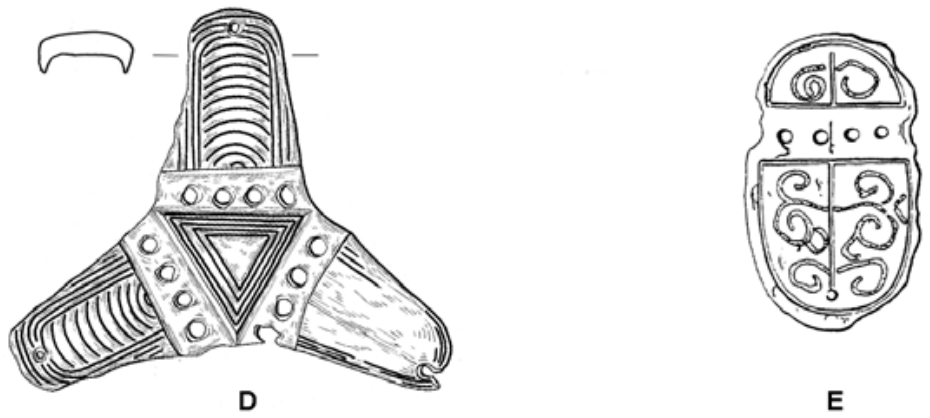

E

Ryc. 3. Okucia trójlistne - A: Staré Město/cz (Galuška 1997: obr. 5).

B: Bojná-Valy/sk (Pieta, Ruttkay 2007: obr.7). C: Dolný Kubín-Vel'ký Bysterec/sк (Robak 20I4: Tab. LII: I). D: Dolné Vestenice/sk (rys. N. Vaššová).

Okucie owalne - E: Pobedim (Bialeková 2002: obr. 5: 6). A, C - żelazo; B - żelazo tauszowane mosiądzem; D, E - żelazo tauszowane srebrem. 
znaleziska pochodzącego z Europy Zachodniej lub Skandynawii. Z drugiej jednak strony, iluminacje większości z karolińskich rękopisów, na których wyobrażono garnitury mieczowe, przedstawiają właśnie ten model (Robak 2013: Tab. CXv), co sugeruje, że był on tam znany. Co więcej, luźne znaleziska okuć dachowatych nie należą w Europie Zachodniej do zupełnych wyjątków, choć jest ich relatywnie mało, a część mogła należeć do innych typów garniturów.

Jako ciekawostkę można przytoczyć fakt, że w zespołach M-375 i Jarohněvíce garnitur typu II towarzyszył mieczom typu $\mathrm{x}$ (co też sugeruje jego użytkowanie głównie w 2. poł. IX w.), podczas gdy iluminacje w karolińskich rękopisach przedstawiają raczej model głowicy zbliżony do typu specjalnego I, a więc typu dużo wcześniejszego. Należy jednak zauważyć, że iluminacje są wykonane w pewnej konwencji, stąd trudno oczekiwać od artystów głębszej refleksji nad typologią przedstawianego uzbrojenia. Fakt, że na wszystkich iluminacjach miecz wygląda bardzo podobnie, budzi podejrzenia, że artysta/artyści korzystali z jakiegoś wspólnego wzorca ikonograficznego lub kopiowali od siebie.

Typ III

Trzeci typ garnituru mieczowego, zamiast trójlistnego rozdzielacza, zawierał okucie z dwiema przewleczkami, które umożliwiało rozdzielenie rzemieni na podobnej zasadzie. Występowanie tego typu garnituru mieczowego, jak dotąd, jest ograniczone do północno-zachodnich obszarów państwa karolińskiego (Robak 20I4: Mapa 13). Na podstawie stylistyki zdobienia poszczególnych elementów garniturów typu III (prostokątne, rzadziej trapezowate formy z pogrubionymi walcowato brzegami) można datować użytkowanie tego typu garniturów na drugą połowę IX w., przy czym próby uściślenia chronologii wskazują raczej na ostatnią tercję IX w. (Robak 20I3: I46-I47). Byłby to więc najmłodszy typologicznie garnitur o czysto karolińskiej genezie. Nie ma, jak dotąd, dowodów na użytkowanie garniturów typu III na obszarach wschodnich peryferii Imperium Karolińskiego, choć pojedyncze okucia rzemieni wykonane w podobnej stylistyce znane są z obszarów Moraw (okucie końca rzemienia z BP-253) oraz ze Słowenii.

\section{Typ IV}

Czwarty typ garnituru mieczowego składał się z okucia z szyjką, okucia dachowatego, okucia z przewleczką oraz relatywnie krótkiego (w porównaniu do poprzednich typów) zakończenia pasa. W przeciwieństwie do pozostałych typów, brak w nim trójkierunkowego rozdzielacza rzemienia, występuje natomiast okucie z szyjką zakończoną oczkiem, przez które można było przewlec rzemień. W żadnym z odnalezionych i opublikowanych dotąd garniturów nie było też sprzączki. 

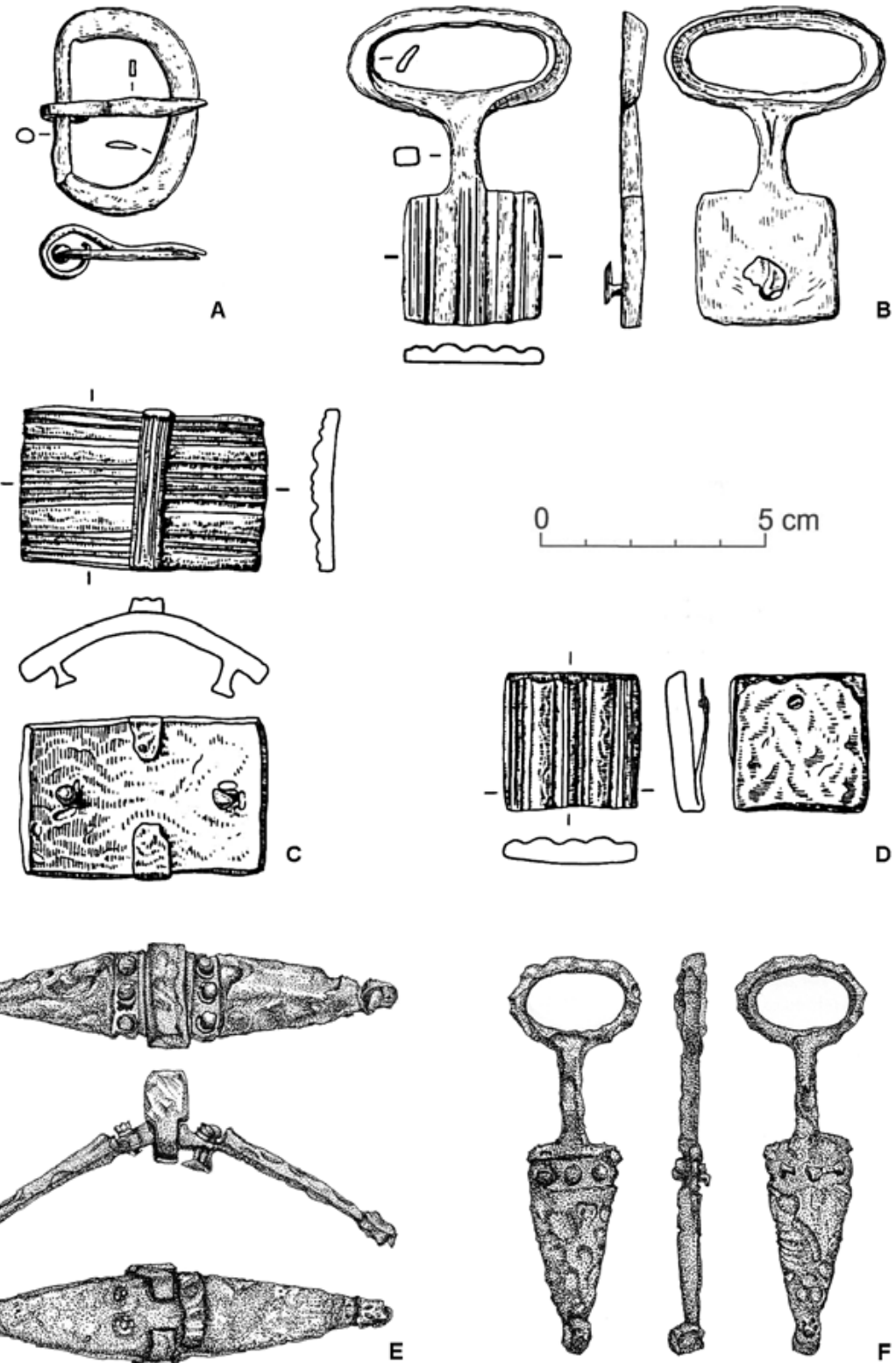

Ryc. 4. Elementy garnituru mieczowego typu IV. A-D: Bojná-Valy/sk (Archiwum AÚ SAV Nitra/Jakubčinová 20I8). E-F: Brno-Lišeň - Staré Zámky (Kouřil 2013: Abb. 5). Żelazo. 
Rekonstrukcja funkcjonowania tego typu garnituru jest częściowo hipotetyczna, opiera się bowiem na zdekompletowanych zestawach i jednym zespole zwartym $(\mathrm{R}-7 \mathrm{I})$, stąd nie jest jasne, czy okucie z szyjką w garniturze typu IV zastąpiło trójkierunkowy rozdzielacz czy też sprzączkę. Obie możliwości użycia tego elementu są równie prawdopodobne, przy czym nie wykluczają innych ${ }^{6}$.

Zagadkowy brak sprzączki, która powinna się w garniturze znaleźć, może być tylko dziełem przypadku i wynikać z niewielkiej liczby znanych zestawów, w których akurat sprzączka się nie zachowała. Na przykład okucia ze stanowiska Bojná-Valy na Słowacji (ryc. 4: A-D) wyglądają jak komplet, a razem z okuciem z szyjką odnaleziono w trakcie wykopalisk pasującą rozmiarami sprzączkę. To potwierdzałoby obecność tego elementu w garniturze typu Iv. Niestety, dwa przedmioty (okucie dachowate i zakończenie pasa) odebrano poszukiwaczom zabytków i nie wiadomo, gdzie dokładnie na stanowisku je znaleźli. Jednakże można przypuszczać, że wszystkie cztery przedmioty, ze względu na swoje niestandardowo duże rozmiary i podobny, dość charakterystyczny, a jednocześnie niepowtarzalny wygląd, mogły stanowić (niepełny?) zestaw tworzący garnitur typu IV.

Występowanie garniturów typu IV jest charakterystyczne wyłącznie dla obszarów wschodnich peryferii Imperium Karolińskiego. Zdekompletowane zestawy dotychczas zostały odnalezione tylko na terenach Moraw, zachodniej Słowacji oraz Słowenii (ryc. 4; Robak 2013; Kouřil 2013), z terenów tych pochodzi także kilka luźnych znalezisk okuć dachowatych. Oprócz tego okucia dachowate są znajdowane na obszarze Kotliny Czeskiej. Choć teoretycznie okucia te mogły stanowić części garniturów typu II, to stylistyka ich zdobienia wskazuje raczej na to, że pochodzą one z garniturów typu IV. Hipotezę tę wzmacnia fakt, że, jak dotąd, na terenie Słowenii w ogóle nie odnaleziono elementów garniturów typu I oraz II.

Użytkowanie garniturów typu IV datować można na drugą połowę IX w. i początek $\mathrm{X}$ w. Ponieważ większość znalezisk to znaleziska luźne, trudno je powiązać z konkretnymi typami mieczy. Datowanie to opiera się głównie na stylistyce zabytków, niemal identycznej jak stylistyka lepiej datowanych elementów garniturów typu v oraz współwystępowaniu obu tych typów na stanowiskach lub w zespołach (jednostkach stratygraficznych) o możliwej do określenia chronologii. Garnitur z pochówku R-7I, w którym odnaleziono także miecz t. Y (Hošek i in. 2019b: 232), może być datowany na przełom IX i X w., co mieści się w wyznaczonych granicach chronologicznych.

6 Ostatnio zasugerowano na przykład (Hošek i in. 2019b: 125), że okucie to mogło stanowić element regulujący długość rzemienia pomocniczego. To mało prawdopodobne, gdyż to w większości znanych przypadków zapewniało okucie z przewleczką. Być może jednak garnitury typu IV, a także v, miały jakieś (jeszcze nierozpoznane) warianty, lub też, doraźnie, radzono sobie, zastępując brakujące elementy innymi i na taki natrafili wspomniani badacze (garnituru KZ-3 nieopublikowano). 


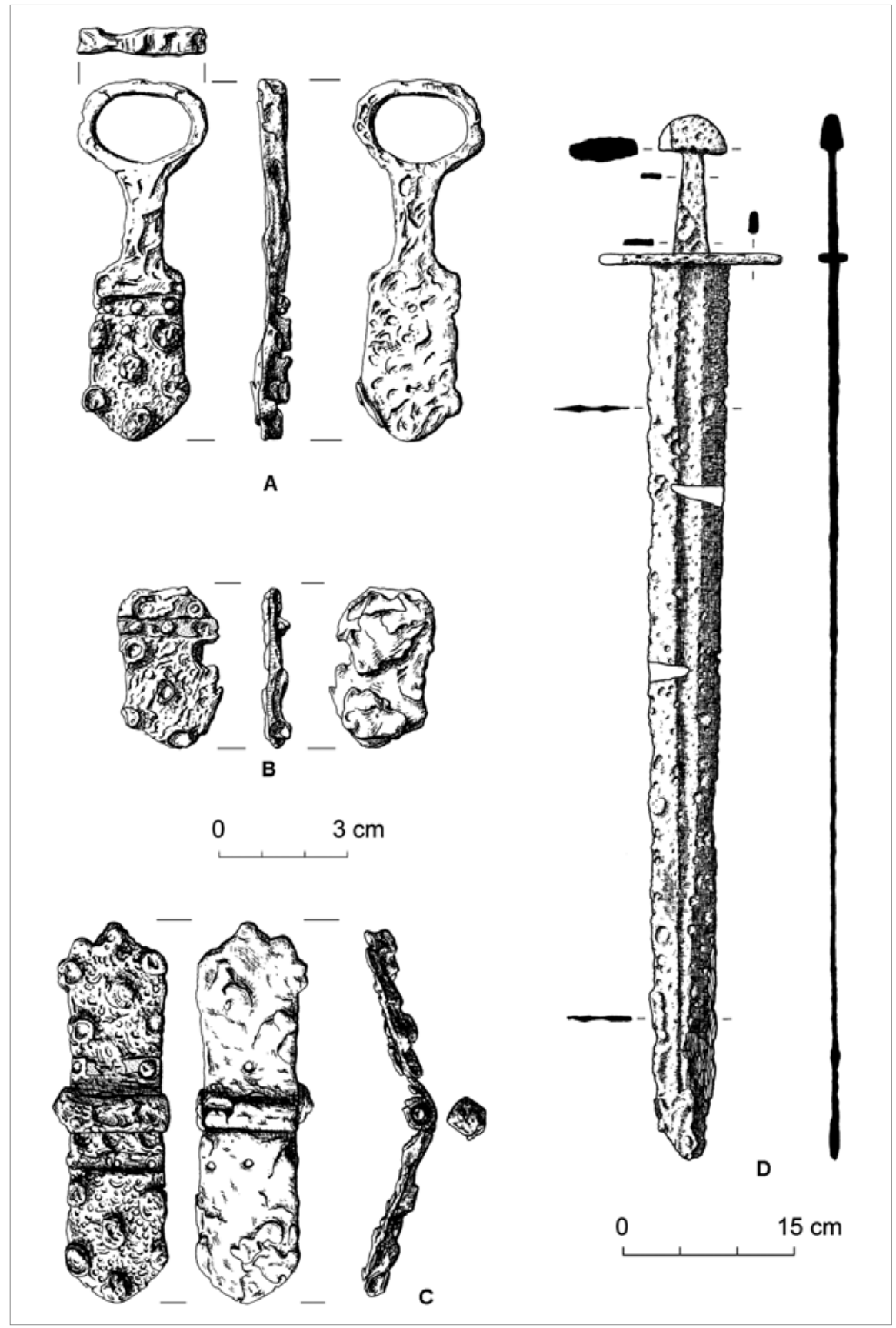

Ryc.5. Závada/sk, gr. 23. Garnitur typu v - A: okucie z szyjką; B: okucie końca rzemienia; c: okucie z zawiasem; D: miecz typu x (rys. Ž. Nagyová). Żelazo. 
Typ V

Piąty typ garnituru mieczowego składał się z okucia z szyjką, okucia z zawiasem, okucia z przewleczką oraz zakończenia pasa. Podobnie jak w przypadku typu IV, dotychczas nie odnaleziono kompletu, który zawierałby sprzączkę. Rekonstrukcja funkcjonowania tego typu garnituru jest zatem także częściowo hipotetyczna, choć opiera się na większej liczbie znalezisk, aniżeli w przypadku garnituru typu IV. Zasadniczą różnicą pomiędzy oboma typami jest zastąpienie okucia dachowatego

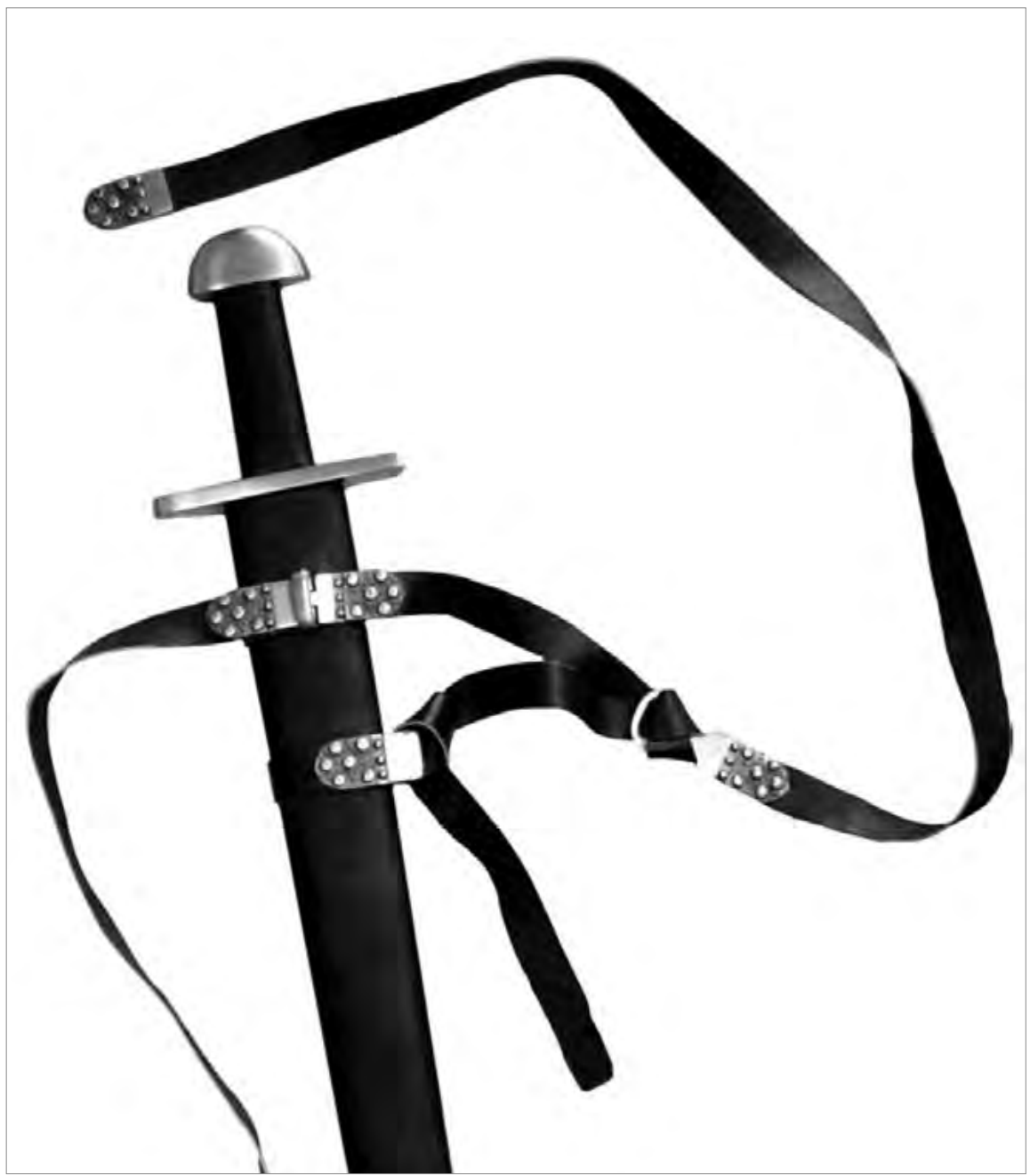

Ryc.6. Eksperymentalna rekonstrukcja garnituru mieczowego typu $\mathrm{v}$ (autorzy: Z. Robak, M. Knoll). 
Garnitury okuć rzemieni i inne elementy ozdobne wielkomorawskich mieczy

podobnym okuciem, ale z umieszczonym pośrodku zawiasem, który czynił połowy okucia ruchomymi względem siebie (ryc. 5-7). Pomimo tej zmiany, jak się wydaje, oba typy okuć spełniały identyczną funkcję. Okucie z zawiasem występuje tylko w garniturze typu v, co ułatwia identyfikację niepełnych zestawów oraz umożliwia przypisanie typowi $\mathrm{v}$ pojedynczych znalezisk.

Występowanie garniturów typu $\mathrm{v}$ jest charakterystyczne wyłącznie dla obszarów wschodnich peryferii świata karolińskiego, aczkolwiek znaleziska ograniczają się tylko do obszarów Moraw, zachodniej Słowacji oraz Słowenii. Obszary znalezisk garniturów typu V oraz pojedynczych i uszkodzonych okuć z zawiasem w zasadzie pokrywają się, z dość wyraźną koncentracją na obszarze zachodniej Słowacji, co może być jednak tylko wynikiem stanu badań.

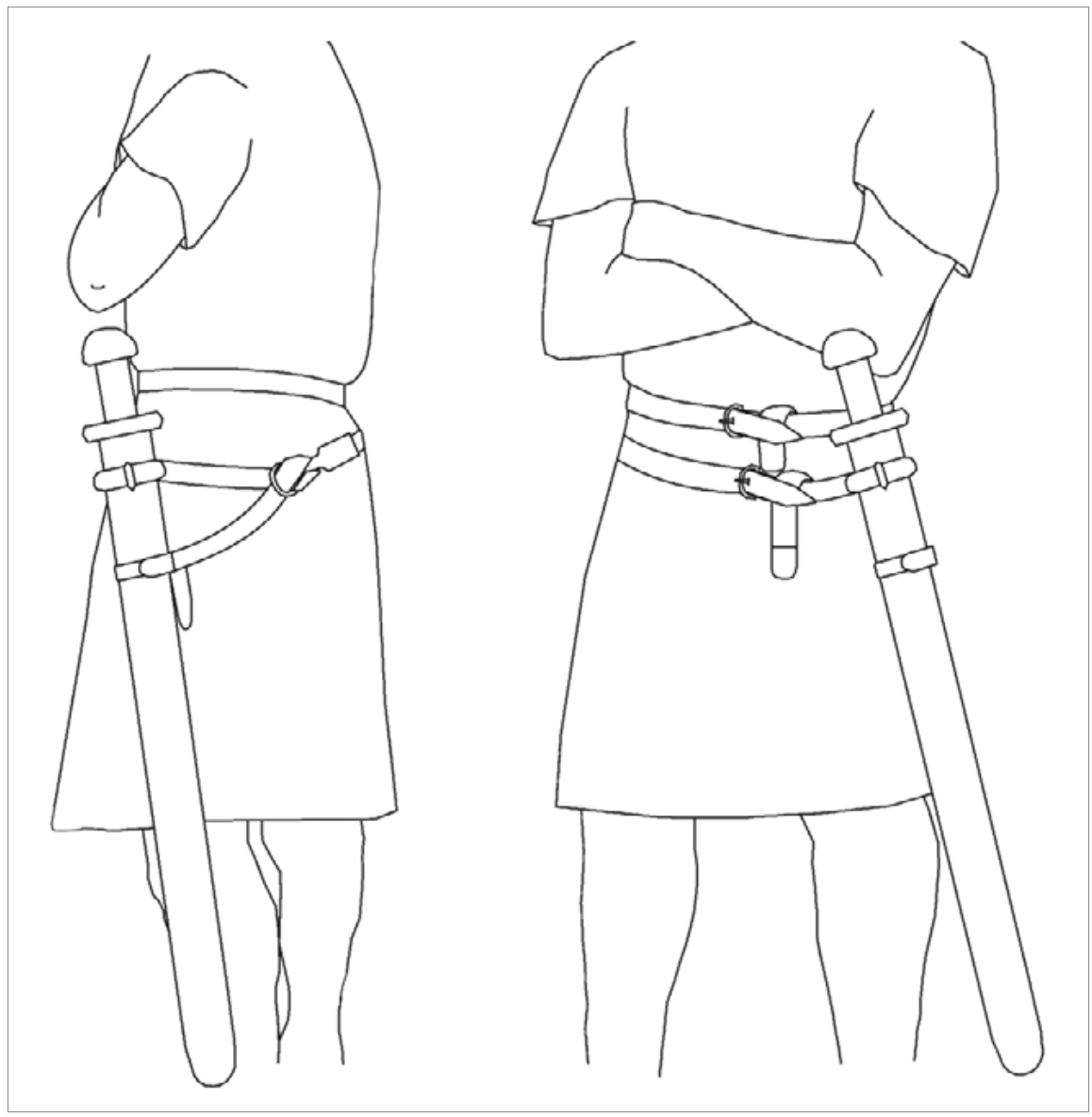

Ryc.7. Sposób mocowania okuć w garniturach typu IV oraz V (rys. Z. Robak).

37 

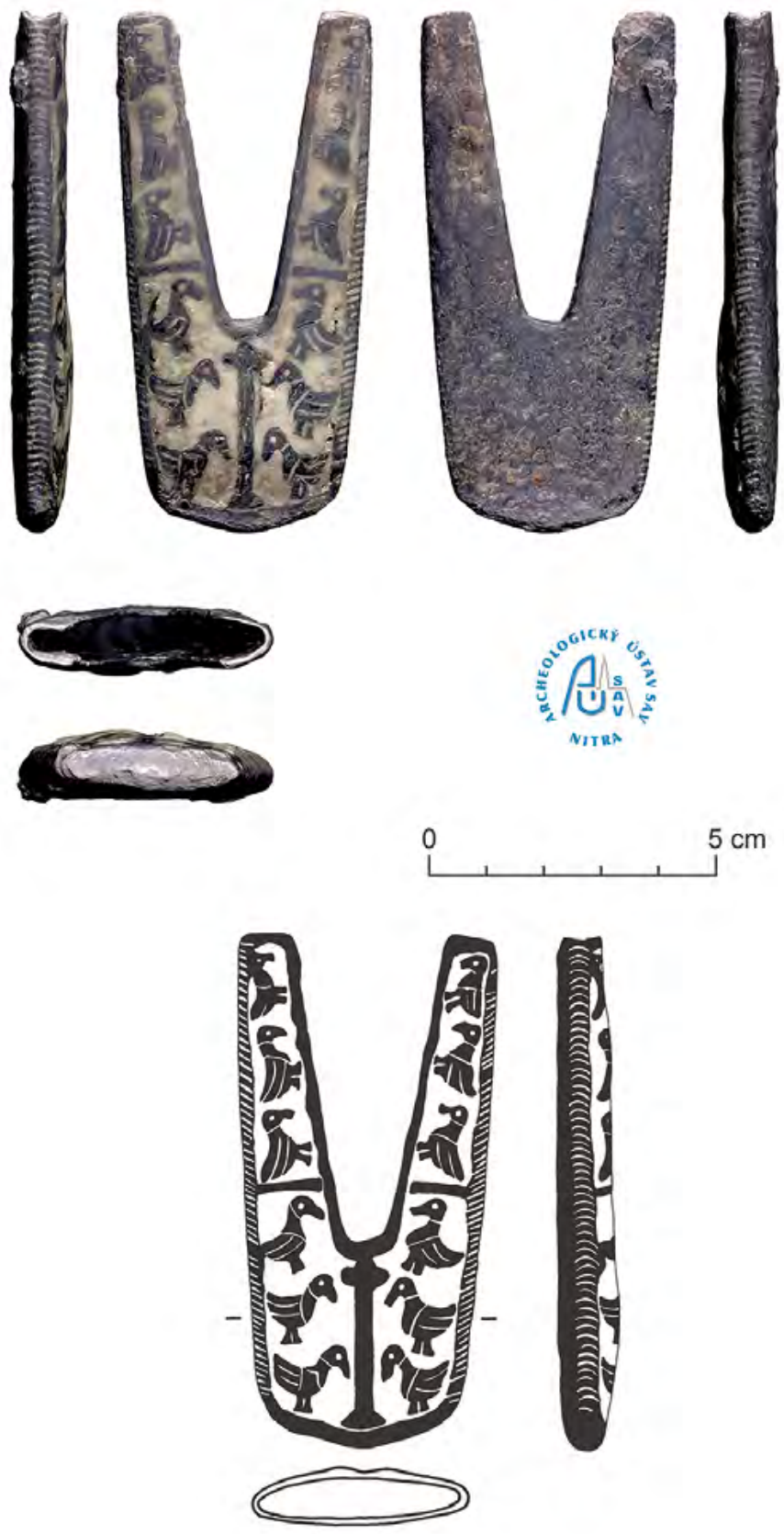

Ryc.8. Bojná-Valy/sk. Trzewik pochwy miecza. Żelazo, srebro (Archiwum aú sAV Nitra/Pieta 20I7: obr. I5:II; 3D render: A. Arpaš, M. Ruttkay, rys. N. Vaššová). 
Użytkowanie garniturów typu $\mathrm{V}$ można ramowo datować na drugą połowę IX w. i początek X w. Stosunkowo dużą liczbę elementów tego typu garnituru (a także kilku elementów typu IV) pochodzącą z grodziska Bojná-Valy łączyć można ze schyłkową fazą istnienia tam obiektu obronnego, datowaną dendrochronologicznie na schyłek IX i pierwsze dekady X w. (Pieta, Robak 2017; Robak 202I). Garnitur z pochówku $23 \mathrm{w}$ nieodległej Závadzie, który towarzyszył mieczowi typu X, także można datować na ten okres (Robak 20r8a). Bardzo charakterystyczne dla elementów garnituru typu $\mathrm{v}$ jest zdobienie plastyczne za pomocą wielkich guzów z wyrytym motywem krzyża lub kilku mniejszych rozdzielonych plastycznym żeberkiem. Wszystkie znane do tej pory garnitury typu v oraz luźne znaleziska, które można mu przypisać, zostały wykonane z żelaza.

\section{Pochwa miecza i trzewik}

W niemal wszystkich wielkomorawskich pochówkach z mieczami na mieczach zachowały się ślady drewna świadczące o tym, że broń do grobów została złożona w pochwach. Na podstawie wykonanych analiz udało się ustalić, że wykonywano ją z drewna drzew liściastych (np. grabu lub topoli). Szczegółowe analizy niektórych znalezisk ujawniły też ślady tekstyliów oraz skóry, a w rzadkich przypadkach także drobnych metalowych elementów w postaci małych nitów lub fragmentów blachy. Nie jest oczywiście do końca pewne, czy w każdym przypadku tekstylna powłoka tworzyła część pochwy, czy też niektóre ślady stanowią resztki szaty pochowanego lub całunu. Jednak badacze analizujący znaleziska wczesnośredniowiecznych mieczy z obszarów całej Europy (Cameron 2000; Geibig 1991: 104-106) potwierdzają, że pochwy mieczy wykonywane były z wielu warstw różnorodnych materiałów (drewna, skóry, futra czy tkanin). Ustalenia te dość dobrze korespondują z informacją Mnicha z St. Gallen (Notker der Stammler, I, 34) o tym, jak była skonstruowana pochwa miecza frankijskiego króla - miecz był zawinięty w pochwe, pokryta skórą i najbielsza lniana tkanina powleczona lśniacym woskiem ${ }^{7}$. Podobnie skonstruowane były pochwy bizantyńskich mieczy (Kolias 1988: 148). Nie ma powodów przypuszczać zatem, że pochwy frankijskich mieczy używanych przez zamożniejszych Morawian odbiegały od ogólnoeuropejskiego technologicznego standardu. Zapewne, w zależności od majętności właściciela, jakość wykonania mogła się różnić - począwszy od pochew wykonanych tylko z drewna i skóry, po takie wykonane z użyciem kilku warstw materiałów, a nawet futra i zdobione okładzinami z metali (także szlachetnych) oraz wytłoczeniami

$7 \mathrm{Na}$ specjalne okazje król posiadał także miecz wysadzany drogimi kamieniami (zapewne chodziło o głowicę lub pochwę). 
na skórze (Košta, Hošek 2008a; 20I4: 288-294). Standardem było także owijanie pochwy dodatkowymi rzemieniami, co miało ją wzmacniać i chronić, a także zdobić. Rzemienie te mogły być wytłaczane we wzory.

Niewielkie fragmenty miedzianej lub żelaznej blachy i małe nity, które zachowały się na pochwach wielkomorawskich mieczy, sugerują, że niektóre egzemplarze mogły być dodatkowo wzdłuż obwodu wzmacniane metalowymi taśmami. Taśmy te, w zależności od sposobu wykonania, mogły też pełnić funkcję dekoracyjną. Wzmacniane ozdobną blachą mogło być też żeberko lub górna część pochwy miecza. Znaleziska pozostałości takich elementów należą jednak do wyjątków.

W żadnym z wielkomorawskich pochówków nie odnaleziono natomiast trzewika pochwy miecza, podobnie zresztą jak brak ich we współczesnych im pochówkach z zachodu Europy. Karolińskie trzewiki pochwy mieczy w ogóle nie są znane, poza kilkoma dawnymi znaleziskami datowanymi na schyłek viII w. (Geibig 1991: 107-III). I w tych przypadkach chodziło jednak raczej o wyżej wspomnianą ozdobną blachę lub taśmę czy drut (albo w ogóle rzemień przesycony produktami korozji, który mógł zdawać się pozostałością metalu), a nie typowy masywny metalowy trzewik. Także karolińskie źródła ikonograficzne ${ }^{8}$ wyobrażające postacie z mieczami dość dobitnie świadczą o tym, że w IX w. trzewików $\mathrm{z}$ reguły nie stosowano, a pochwy mieczy owinięte były rzemieniami (Robak 2013: rys. 47; 20I4: Tab. CXII-CXVII). Na większości iluminacji rękopisów pochwa miecza owinięta jest równoległymi i krzyżującymi się rzemieniami tworzącymi wzmocniony koniec. Wyjątek stanowi iluminacja Biblii św. Pawła (fol. 334v, cIr; Robak 20I4: Tab. CXVI), na której postać trzyma miecz, którego pochwa zakończona jest asymetrycznym U-kształtnym trzewikiem, przypominającym bardziej ówczesne okucia pochew noży. Wydaje się zatem, że w czasach karolińskich główną atrakcję wizualną stanowić miały raczej okucia rzemieni służące do mocowania miecza do pasa.

Do unikatów zatem należy trzewik pochwy miecza znaleziony na grodzisku Bojná-Valy na Słowacji (ryc. 8; Pieta 2017: 29). Przedmiot ten wykonano z żelaza, jego lico jest platerowane srebrną folią, a dłuższe boki tauszowane srebrnym drutem. Żelazne płytki, których użyto do sporządzenia trzewika, są bardzo masywne. Trzewik zdobi przedstawienie dwunastu ptaków oraz figury przypominającej wysoki krzyż na cokole. Motywy ornamentacyjne wykonano w technice niello, a detale, takie jak oczy i skrzydła ptaków, za pomocą tauszowania. Trzewik ma kształt lekko zaoblonego, wydłużonego trapezu o długości 9,I cm.

8 Szkice w Geibig 1991: Abb. 29 są dość schematyczne i dalece odbiegają od oryginalnych iluminacji. 
Ponieważ technika wykonania (tauszowanie, niello) była w pełni dostępna zarówno dla rzemiosła karolińskiego, jak i wielkomorawskiego, trudno stwierdzić, czy mamy tu do czynienia z importem, czy też produkcją miejscową. Motywy dekoracyjne na trzewiku są jednak właściwe dla IX-wiecznej symboliki chrześcijańskiej. Motyw krzyża i ptaków w sztuce i rzemiośle wielkomorawskim oraz karolińskim i karolińsko-ottońskim pojawia się dość często (Wamers 1986: 22-33; 2005: 308-3I0; 2008: 49-50; Die Macht... 2005), istnieją nawet całe grupy zabytków (fibul i okuć pasa) wykorzystujących ten schemat (Robak 20I4: Tab. CI). Możemy się w nim doszukiwać alegorii raju, drzewa życia czy w przypadku tego konkretnego okucia na przykład dodatkowo symboliki dwunastu apostołów. Motywy samych ptaków w ogóle dość często pojawiają się na wielkomorawskich okuciach rzemieni, gombikach i innych ozdobach (Velká Morava... 20I4), a motyw krzyża, w różnych formach, należy uznać za niemal standardowy dla tych przedmiotów (Robak 2019). Niemal identyczna figura ptaka została wyobrażona na przykład na okuciu rzemienia z gr. 190/50 w Starym Měscie. Stylistycznie zatem trzewik z Bojnej dość dobrze wpisuje się w wielkomorawską estetykę stroju elitarnego wojownika.

Trzewik nie przypomina ani kształtem, ani techniką wykonania znanych starszych merowińskich czy anglosaskich zakończeń pochew mieczy (Menghin 1983), czy też charakterystycznych trzewików mieczy skandynawskich (Paulsen 1953: I4). Należy go traktować jako kompletny ewenement, być może wykonany na czyjeś specjalne życzenie. Ponieważ, jak się wydaje, stosowanie trzewików pochew mieczy w IX w. na obszarze Europy nie było zbyt popularne (trzewiki wikińskie datowanie na IX w. są niezmiernie rzadkie), być może zamawiający zasugerował się bizantyńskim uzbrojeniem, w którym trzewiki pochwy miecza były wówczas stosowane (Hoffmeyer 1966: 98; Kolias I988: I49; Grotowski 2011: 395-398). Wykonanie pozostawił jednak miejscowemu producentowi, który zrobił to tak, jak umiał i ozdobił przedmiot zgodnie z lokalną i aktualną modą.

\section{Podsumowanie}

Podstawowe typy garniturów mieczowych, które udało się zidentyfikować na podstawie znalezisk archeologicznych i źródeł ikonograficznych, z całą pewnością nie wypełniają wszystkich stosowanych w okresie karolińskim sposobów mocowania miecza do pasa. Można przypuszczać, że doraźnie stosowano jakieś kombinacje znanych typów okuć, noszono „wybrakowane” garnitury lub stosowano tylko ozdobne zakończenia rzemieni podtrzymujących miecz (BP-257). Na przykład pochówki 190/50 i 223/51 ze Starego Města (Hrubý I955: 49I-492, 524-525), których wyposażenie zawierało m.in. miecz, ostrogi i po kilka kompletów pozłacanych okuć różnych rzemieni (gr. 190/50 dodatkowo pasa głównego), nie zawierały garniturów mieczowych, a jedynie ozdobne zakończenie rzemienia mieczowego, 
choć niewątpliwie status materialny i społeczny pochowanych pozwalałby im na posiadanie całego zestawu okuć.

Co interesujące, w pochówkach wielkomorawskich w ogóle nie stwierdzono wyraźnego związku pomiędzy zdobieniami głowicy i jelca miecza a estetyką towarzyszącego mu garnituru mieczowego, tak jakby miecz i garnitur zapięć nie stanowiły kompletu (przeciwnie do zapięć noży bojowych, które zazwyczaj stanowiły stylistyczny komplet ze zdobioną okładziną pochwą). Co więcej, w tych pochówkach, w których znaleziono miecze ze zdobionymi głowicami i jelcami (np. SM-116/51; SM-223/51; SM-119/AZ; M-265), a były to najczęściej miecze typu B/H i K, garniturów mieczowych albo w ogóle nie było, albo składały się jedynie ze sprzączki (czasem z przewleczką) i okucia końca rzemienia - niekiedy pozłacanego, niekiedy najprostszego żelaznego. Garnitury mieczowe występują w zespołach najczęściej z niezdobionymi mieczami typu X i Y. Rodzą się zatem pytania, czy zdobienie mieczy typu $\mathrm{H}$ i $\mathrm{k}$ było dla ich właścicieli na tyle satysfakcjonujące, że nie stosowano już garnituru mieczowego? A może garnitury mieczowe upowszechniły się dopiero później, kiedy rozpoczął się już napływ (a może i lokalna produkcja) zazwyczaj niezdobionych młodszych mieczy typu N/X i Y? A może moda na garnitury mieczowe była właśnie reakcją na uproszczenie zdobienia głowic mieczy, które docierały na Morawy w drugiej połowie IX w.? Te przypuszczenia mogą potwierdzać znaleziska z cmentarzysk w Starym Měscie, z których pochodzi największy zbiór mieczy karolińskich wczesnych typów (specjalny, B/H), w większości o zdobionych głowicach $\mathrm{i}$ jelcach. Jednak w pochówkach nie znaleziono żadnego typowego garnituru mieczowego (jedyny element garnituru mieczowego z tego gigantycznego stanowiska - okucie trójlistne - znaleziono w wypełnisku fosy - ryc. 3: A). Jest to kwestia interesująca zarówno z punktu widzenia chronologii przedmiotów, jak i intensywności i charakteru wpływów karolińskich na terenach dorzecza środkowego Dunaju. Szczególnie, że w karolińskich pochówkach z końca viII w. i pierwszej tercji IX w. z obszaru Dalmacji tym samym starszym typom mieczy (specjalny, H, K) najczęściej towarzyszyły garnitury mieczowe lub komplety okuć stylistycznie zgodne ze zdobieniami jelca i głowicy (Vinski 198I; Jurčević 20II). Należy przy tym dodać, że do „morawskich” mieczy typu specjalnego I, B/H czy K dałoby się wśród znalezisk z całej Europy dobrać pasujące do nich stylistycznie garnitury mieczowe. Elementy takich garniturów jednak na Morawy nie docierały, ewentualnie docierały sporadycznie (ryc. 3: E).

Oczywiście do noszenia miecza na biodrach nie potrzebne były żadne okucia rzemienia, może z wyjątkiem sprzączki do spięcia pasa, choć ten da się zawiązać i bez niej. Pomimo dużej liczby zachowanych elementów garniturów mieczowych (okuć, sprzączek, łączników itp.), badacze zgodnie twierdzą, że żaden z nich nie był w tym zestawie niezbędny, a jego funkcję z powodzeniem mogły zastąpić zwykłe nity, materiały organiczne, szwy czy węzły. Nawet żeberko pochwy miecza nie stanowiło 
niezbędnego elementu, dało się je zastąpić pętlą wykonaną z rzemienia lub przewlec pas przez otwory w pochwie miecza. Okucia pełniły więc przede wszystkim funkcję ozdobną, niekiedy wręcz w sposób ostentacyjny informowały o statusie społecznym właściciela, choć niewątpliwie niektóre z elementów (np. sprzączki czy okucia z przewleczką) znacznie usprawniały funkcjonowanie zawieszenia miecza. Popularność okuć rzemieni miecza była raczej wynikiem mody połączonej z informacjąo pozycji społecznej właściciela. To następnie inspirowało także niższe warstwy, które starały się w miarę swoich możliwości kopiować trendy ustalane przez elity. Uwidacznia się to w całym spektrum jakości i precyzji wykonania garniturów mieczowych - od pozłacanych okuć z metali kolorowych, zdobionych różnymi technikami (niello, tauszowanie, filigran, kamienie itd.) po najprostsze żelazne okucia wykonane w kuźniach. Możemy domniemywać, że, podobnie jak to było w przypadku stroju, moda panująca wśród karolińskiej szlachty była pewnego rodzaju punktem odniesienia dla morawskich Słowian, a zatem i w przypadku sposobu zapinania i zdobienia miecza wzorowano się na wyglądzie karolińskich wojowników. Niektóre elementy, takie jak na przykład trójlistne rozdzielacze rzemieni, przejęto wprost, w przypadku innych mamy jednak do czynienia z rozwiązaniami technicznymi nieznanymi na obszarze Europy Zachodniej (np. okucie z zawiasem). Do upowszechnienia się tych wzorców $\mathrm{i}$ ich przetworzenia potrzeba było jednak czasu.

Jak się wydaje, z początkami intensywnych wpływów karolińskich na obszar dorzecza środkowego Dunaju mamy do czynienia od drugiej dekady IX w. Tłumaczy to niemal zupełny brak wyrobów w stylu wczesnokarolińskim (np. zdobionych w stylu kielicha księcia Tassilona) oraz niewielką liczbę znalezisk ozdób we wczesnym stylu roślinnym, charakterystycznym dla epoki późnokarolińskiej (IX - pocz. X w.). Wówczas to napływają na teren Moraw miecze typu specjalnego I, 2 oraz B/H i K, ostrogi płytkowo-nitowe i różne zestawy okuć rzemieni. Garnitury mieczowe pojawiają się jednak nader rzadko (w zasadzie jedynym kompletem, w dodatku pochodzącym z terenu Kotliny Czeskiej, jest garnitur t. I z gr. SK-55). Wszystkie te wyroby były używane głównie przez członków elit i drużyn, o czym świadczy zarówno wysoki standard ich wykonania, jak i ich późniejsza obecność w bogato wyposażonych pochówkach. Wszystkie też stanowią importy z zachodu Europy lub też są ich bezpośrednimi kopiami. Prawdopodobnie ich produkcją zajmowała się ograniczona liczba wyspecjalizowanych warsztatów. Dowodem na to jest niemal jednolite wzornictwo tych wyrobów oraz znaleziska niemal identycznych przedmiotów na niekiedy bardzo oddalonych od siebie obszarach Europy objętych wpływami karolińskimi? .

9 Na przykład bliźniaczy element garnituru z gr. SK-55 „odnalazł się” aż w Schouwen w Holandii (Capelle 1978: Taf. 13: 62). 
$\mathrm{Z}$ upowszechnieniem się zwyczaju noszenia garniturów mieczowych na Morawach i zachodniej Słowacji mamy do czynienia w drugiej połowie IX w. Zapewne była to w dużej mierze reakcja na identyczny trend, który rozpoczął się trochę wcześniej na terenach Imperium Karolińskiego. O ile elementy karolińskich garniturów mieczowych, zdobione w stylu geometrycznym lub wczesnym roślinnym charakterystycznym dla pierwszej tercji IX w., dadzą się wśród znalezisk archeologicznych identyfikować, wciąż są jednak dość rzadkie, o tyle znaleziska karolińskich elementów garniturów mieczowych datowanych głównie na drugą tercję IX w. liczymy już w setkach (Robak 2013; 20I4). Trend ten słabnie w ostatniej tercji IX w., kiedy to zestawy okuć rzemieni miecza tracą na popularności. Nie jest przy tym jasne, czy był to tylko efekt zmian w modzie, czy też skutek „drenowania” karolińskich zasobów metali szlachetnych i kolorowych bezustannymi wojnami prowadzonymi ze wszystkimi sąsiadami oraz łupieżczymi rajdami Skandynawów. Ponieważ gros znalezisk karolińskich ozdób, w tym garniturów okuć, pochodzi ze znalezisk depozytów i pochówków z obszarów zasiedlonych przez Skandynawów, należy przypuszczać, że odpływ w tym kierunku musiał być znaczny. Ogromna ilość karolińskich zasobów cennych metali trafiała w ręce Skandynawów w drodze wymiany handlowej, jako dary, ale głównie jako okup bądź łupy.

Większość wielkomorawskich garniturów mieczowych i znalezisk pojedynczych elementów także jest datowana na drugą połowę IX w. O ile jednak garnitury mieczowe, podobnie jak inne zdobione elementy wyposażenia wojownika, takie jak ostrogi i okucia rzemieni, datowane na pierwszą połowę IX w. wykazują cechy stylistycznie zgodnie z zachodnioeuropejskimi wzorami, to w drugiej połowie dochodzi do rozłamu, skutkującego powstaniem stylistyki charakterystycznej dla wschodnich peryferii świata karolińskiego (dzisiejsze Czechy, Morawy, zachodnia Słowacja, Węgry, Słowenia, Austria, wschodnia Bawaria). Stylistyka ta generalnie hołdowała ogólnokarolińskim trendom (prostokątne kształty, dzielenie pól ornamentacyjnych, motywy oparte na krzyżu), nosiła jednak bardzo wyraźne cechy lokalne. Równocześnie na Morawach zauważalny jest spadek liczby luksusowych importów zachodnioeuropejskich, na przykład przedmiotów zdobionych w rozwiniętym stylu roślinnym. Wówczas też na obszarze wschodnich peryferii Imperium Karolińskiego pojawiają się nowe typy garniturów (IV oraz V), które na zachodzie Europy nie występują. Nie jest jednak na razie jasne, czy ich pojawienie się to efekt ograniczenia importu, czy odwrotnie - ograniczenie importu nastąpiło na skutek podjęcia intensywnej lokalnej produkcji elementów uzbrojenia i wyposażenia wojowników. Trend spadku importów z zachodu Europy nasila się z czasem - ozdoby wykonane w stylistyce charakterystycznej dla schyłku IX w. (tzw. „barokowy” styl roślinny, motywy zwierzęce, tzw. styl karolińsko-ottoński, garnitury mieczowe typu III) w zasadzie na Morawach się nie pojawiają. 
W drugiej połowie IX w. na Morawach zauważalna jest za to wyraźnie „pauperyzacja" modelu wojownika. Ogromna liczba znalezisk, nie tylko garniturów mieczowych, ale też ostróg, mieczy i innych elementów wyposażenia wojownika, to przedmioty dobrej jakości, ale wykonane w prosty sposób, z żelaza, przy minimalnym nakładzie pracy i kosztów. Przyczyn tego zjawiska szukać należy w zmianach organizacji sił zbrojnych, głównie za czasów Świętopełka (860/87I-894), kiedy to mamy do czynienia z nasiloną działalnością militarną połączoną z rozrostem terytorialnym Wielkich Moraw. Warunki polityczne, w jakich znalazło się "państwo" Mojmirowiczów w drugiej połowie IX w., a zwłaszcza w jego ostatniej tercji, sprawiały, że było nieodzowne nieprzerwane utrzymywanie gotowości bojowej dość sporej grupy wojska. Podstawą sił zbrojnych za czasów Świętopełka stali się wyspecjalizowani wojownicy, głównie jazda, wywodzący się z różnych warstw społecznych, nie tylko z arystokracji. Zastąpili oni arystokratyczną drużynę i pospolite ruszenie z czasów Mojmira. Książę zapewniał swoim wojownikom podstawowe uzbrojenie, wyżywienie lub utrzymanie i udział w lupach w zamian za pozostawanie w gotowości bojowej (Ruttkay 1997; Třeštík 1997: 290-29I; Galuška 2017: 176-18I). Miejscami przebywania tych grup były rozmieszczone w strategicznych punktach grodziska oraz bliskie im osady. W źródłach archeologicznych odzwierciedla się to we wzroście znalezisk militariów z drugiej połowy IX w., pochodzących głównie z grodzisk, których powstanie datowane jest na czasy władzy Świętopełka (Robak 202I ${ }^{10}$.

Pojawienie się w drugiej połowie IX w. mody na garnitury mieczowe na Morawach pokazuje, że element ten, jako dodatek do miecza, stał się jednym ze środków manifestacji pozycji społecznej przez osoby zawodowo władające bronią, ale niekoniecznie wywodzące się z najwyższych klas społecznych. Kopiowały one modę panującą wśród arystokracji (która nadal mogła pozwolić sobie na pozyskiwanie najwyższej jakości wyrobów), jednakże trend ten wymusił pojawienie się tańszych, lokalnych produktów, mających za zadanie zaspokojenie potrzeb i aspiracji nawet niższych warstw społecznych $\mathrm{i}$ ich członków zobligowanych do noszenia broni, względnie chcących za takich uchodzić. Zmiany w wyglądzie i typach aplikacji mieczowych znakomicie współgrają ze zmieniającym się wyglądem karolińskich mieczy - żelazne garnitury mieczowe towarzyszą na ogół prostym niezdobionym mieczom z półkolistą głowicą, które od około połowy IX w. zaczęły wypierać zdobione egzemplarze starszych typów z dwudzielną głowicą (Kucypera i in. 20II). Była to broń prosta, ale solidna i zapewne też dużo tańsza.

10 Jak się wydaje, większość wielkomorawskich grodzisk na trenie dzisiejszej Słowacji powstała za czasów Świętopełka, a nie, jak dawniej sądzono, Pribiny (Henning, Ruttkay 20Ir; Robak 2021: 43-63). 
Moda na rozbudowane garnitury mieczowe i w ogóle na rozbudowane garnitury okuć wszelkich rzemieni w karolińskiej Europie kończy się na przełomie IX i X w. Potwierdza to zarówno brak znalezisk przedmiotów tego typu z okresu karolińsko-ottońskiego, jak i zachowana ikonografia, na której podobne detale nie występują. Mieczowe pasy mogą być dekorowane pojedynczymi aplikacjami, podobnymi do prostokątnych fibul (Robak 2013: 90-9I). Znaleziska takich przedmiotów znane są z terenów Europy Zachodniej oraz zachodnich Węgier i Słowenii, aczkolwiek, ze względu na brak tego rodzaju znalezisk w grobach, nie można ich ze stuprocentową pewnością łączyć z garniturami mieczowymi. Niestety, upadek polityczny Wielkich Moraw i rozkład dotychczasowych struktur społecznych i gospodarczych dorzecza środkowego Dunaju w pierwszej połowie $\mathrm{X}$ w. nie pozwala już na stwierdzenie, czy trendy zachodnioeuropejskie byłyby nadal z drobnym opóźnieniem kopiowane i przyswajane przez formującą się (wielko)morawską szlachtę, czy też rozwijanoby wypracowany model lokalny.

Analizy typologiczne i stylistyczne garniturów mieczowych (i w ogóle elementów garniturów okuć rzemieni) pokazują, że były to przedmioty bardzo czułe na zmieniającą się modę i mogą stanowić świetny niezależny wyznacznik chronologiczny zespołów zwartych, o wiele lepszy niż na przykład broń ${ }^{11}$. Dodatkową cechą tych przedmiotów, podobnie jak wszystkich aplikacji związanych z modą, jest fakt, że wydają się one odzwierciedlać nie tylko status majątkowy i społeczny właściciela, ale też, że obserwacje dotyczące zmian i ewolucji ich wyglądu, jakości wykonania i natężenia występowania przydają się w szerszych analizach zmian lokalnych struktur społecznych.

\section{Bibliografia}

\section{Źródła}

Notker der Stammler. Taten Kaiser Karls des Grossen (1959), H.F. Haefele (red.), Weidmannsche Verlagsbuchhandlung, Berlin (Monumenta Germaniae Historica, Scriptores Rerum Germanicum, Nova Series, 12).

11 Na przykład według analizy technologicznej J. Košty, miecz z BP-257 został przerobiony ze starszego egzemplarza (np. typu в czy K lub podobnego), któremu wymieniono oryginalną głowicę na półokrągłą w typie N lub x. Podobnie zmodyfikowano miecz z grobu BPJPII8 (Hošek i in. 2019b: 82-83). Interesująca obserwacja, świadcząca o wartości dobrze wykonanej broni, którą można było użytkować bardzo długo. Świadczy też, niestety, na niekorzyść mieczy jako niezależnych wyznaczników chronologii zespołów. 


\section{Opracowania}

Androŝuk F. (2oII), Meči vikingov, Prostir, Kï̈v.

Balcárková A., Dresler P., Macháček J. (2017), Povelkomoravská a mladohradištní keramika v prostoru dolního Podyji, Filozofická fakulta Masarykova univerzita, Brno (Opera Facultatis philosophicae Universitatis Masarykianae, 476), https://doi.org/ı0.5817/ CZ.MUNI.M210-8866-2017

Baumeister M. (1998), Grundsätzliche Überlegungen zur Rekonstruktion frühmittelalterlicher Schwertgehänge, [w:] B. Berthold i in. (red.), Zeitenblicke. Ehrengabe für Walter Janssen, Verlag Marie Leidorf, Rahden/Westfalen, s. 157-197.

Bialeková D. (1982), Slovanské pohrebisko v Závade, „Slovenská archeológia”, 30 , S. $123-164$.

Bialeková D. (2002), Remeslá a obchod, [w:] A. Ruttkay, M. Ruttkay, P. Šalkovský (red.), Slovensko vo vćasnom stredoveku, Archeologický ústav SAv, Nitra (Archeologica Slovaca Monographiae Studia, 7), s. 89-104.

Cameron E.A. (2000), Sheaths and Scabbards in England AD 400-IIOo, BAR Publishing, Oxford (BAR British Series, 30I), https://doi.org/10.30861/9781841710655

Capelle T. (1978), Die karolingische Funde von Schouwen ${ }_{-2}$, Rijksdienst voor het Oudheidkundig Bodemonderzoek, Amersfoort (Nederlandse Outheden, 7).

Dostál B. (1966), Slovanská pohřebiště ze středni doby hradištni na Moravě, Akademia, Praha.

Galuška L. (1997), Kproblematice predvelkomoravského opevnèni Starého Města, [w:] P. Michna, R. Nekuda, J. Unger (red.), Z pravěku do středověku. Sborník k. 70. narozeninám V.Nekudy, Moravské zemské muzeum, Brno, s. 73-83.

Galuška L. (2017), Slované - stopy předkü. O Moravěv 6.-Io. století, Moravské zemské muzeum, Brno.

Geibig A. (1991), Beiträge zur morphologischen Entwicklung des Schwertes im Mittelalter. Eine Analyse des Fundmaterials vom ausgehenden 8. bis zum I2. Jh. aus Sammlungen der Bundesrepublik Deutschland, Wachholtz, Neumünster.

Geisler M. (2010), Šlapanice u Brna (okr. Brno-venkov), „Přehled vyzkumů”, 5 I, s. $476-477$.

Geisler M. (2013), Středověk a novověk, [w:] K. Geislerová (red.), Výzkumy. Ausgrabungen. 2005-2010, Ústav archeologické památkové péče, Brno, s. 132-164.

Grotowski P.Ł.(2011), Święci wojownicy w sztuce bizantyjskiej (843-I26I). Studia nad ikonografia uzbrojenia i ubioru, Wydawnictwo WAM, Kraków.

Hanuliak M. (2004), Velkomoravsképohrebiská. Pochovávanie v 9.-Io. storoči na území Slovenska, Archeologický ústav SAV, Nitra (Archeologica Slovaca Monographiae Studia, 8).

Helmbrecht M. (2008), Prachtvolle Zeugnisse weitreichender Verbindungen: ein karolingerzeitlicher Neufund vom Aggbichl bei Marquartstein, Lkr. Traunstein, „Bericht der Bayerischen Bodendenkmalpflege", 49, s.367-385.

Henning J., Ruttkay M.(201I), Frühmittelalterliche Burgwälle an der mittleren Donau im ostmitteleuropäischen Kontext. Ein deutsch-slowakisches Forschungsprojekt, [w:] J. Macháček, Š. Ungerman (red.), Frühgeschichtliche Zentralorte in Mitteleuropa. Internationale Konferenz und Kolleg der Alexander von Humboldt-Stiftung zum 
50. Jahrestag des Beginns archäologischer Ausgrabungen in Pohansko bei Břeclav, 5.-9. Io. 2009, Habelt-Verlag, Bonn (Studien zur Archäologie Europas, I4), s. 259-288.

Hoffmeyer A.B. (1966), Military Equipment in the Byzantine Manuscript of Scylitzes in Biblioteca Nacional in Madrid, „Gladius”, 5, s. I-194.

Hošek J., Košta J., Galuška L. (2019a), Re-assessment of two Metallographically Examined Early Medieval Swords from Staré Mèsto (Uherské Hradistè district), Czech Republic, "The Journal of the International Union for Prehistoric and Protohistoric Sciences", 2.I, s. 46-56.

Hošek J., Košta J., Žákovský P. (2019b), Ninth to Mid-sixteenth Century Swords from the Czech Republic in their European Context, part I, The Finds, The Czech Academy of Sciences, Prague-Brno.

Hrubý V. (1955), Staré Mèsto. Velkomoravsképohřebiště „Na valách”, Československá Akademia Věd, Praha (Monumenta Archaeologica, 3).

Jakubčinová M. (2018), Výstroj jazdca a koňa v 9. storočí z územia dnešného Slovenska s prihliadnutím na nálezy v Bojnej. Disertačná práca, Nitra (maszynopis w Archeologický ústav SAV v Nitre).

Jurčević A. (20II), Nalazi ranokarolinškog oružja i konjaničke opreme u doba formiranja Hrvatske Kneževine, „Starohrvatska prosvieta”, III serija, 38, s. III-I47.

Kalousek F. (197I), Břeclav-Pohansko. Velkomoravsképohřebišté u kostela, Univerzita J. Purkyně, Brno (Spisy University J.E. Purkyně v Brně, Filosofická fakulta, 169).

Klanica Z. (1985), Mikulčice-Klášteřrisko, „Památky Archeologické”, 76, s. 474-539.

Klanica Z. (1987), Vorbericht über die Ergebnisse der 32. Grabungssaison in Mikulčice (bez. Hodonin), „Přehled Výskumü”, 30, s. 35-36.

Klanica Z. (2006), Nechvalín, Prušánky. Dil I. Nechvalin, Prušánky: Vier slawische Nekropole, T. 2, Katalog, Archeologický ústav AV Čr, Brno (Spisy Archeologického ústavu AV Čr Brno, 28).

Klanica Z., Kavánová B., Kouřil P., Ungerman Š. (2019), Mikulčice - Die Nekropole an der dreischiffigen Basilika, Archeologický ústav AV ČR, Brno (Studien zum Burgwall von Miklulčice, I2).

Kolias T.G. (1988), Byzantinische Waffen. Ein Beitrag zur byzantinischen Waffenkunde von den Anfängen bis zur lateinischen Eroberung, Verlag der Österreichischen Akademie der Wissenschaften, Wien (Herausgegeben von der Kommission für Byzantinistik der Österreichischen Akademie der Wissenschaften und vom Institut für Byzantinistik und Neogräzistik der Universität Wien, 17).

Košta J. (2005), Kollektion frühmittelalterlicher Schwerter aus dem großmährischen Zentrum in Mikulčice, [w:] P. Kouřil (red.), Die frühmittelalterliche Elite bei den Völkern des östlichen Mitteleuropas mit einem speziellen Blick auf die grossmährische Problematik. Materialien der internationalen Fachkonferenz Mikulčice 15.-26.5.2004, Archeologický ústav AV ČR, Brno (Spisy Archeologického ústavu AV ČR Brno, 28), S. 157-191.

Košta J. (2008), Několik poznámek k chronologii pohřebiště u vI. kostela v Mikulčicich, „Studia Mediaevalia Pragensia”, 8, s. 277-296.

Košta J., Hošek J. (2008a), Mečz hrobu 580 ve III. kostele v Mikulčicich. Príspèvek k diskusi o jednom ze zástupcu nejvyšsí staromoravské elity, „Studia Mediaevalia Pragensia”, 8, s. $177-207$. 
Košta J., Hošek J. (2008b), Zbraně z knižecího hrobu z g. stoletív Koliněz pobledu archeologie a metalografie, „Acta Militaria Mediaevalia”, 4, s. 7-37.

Košta J., Hošek J. (2014), Early Medieval Swords from Mikulčice, Archeologický ústav AV ČR, Brno (Studien zum Burgwall von Miklulčice, Io).

Košta J., Lutovský M. (2014), Raně středověký knižecí hrob z Kolina, Národní muzeum, Praha (Fontes Archaeologici Pragenses, 4I).

Košta J., Hošek J., Dresler P., Macháček J., Přichystalová R. (2019), Velkomoravské meče $z$ Pohanska u Bŕeclavi a okoli - nová revize, „Památky archeologické”, IIO, s. 173-235.

Kouřil P. (2005), Frübmittelalterliche Kriegergräber mit Flügellanzen und Sporen des Typs Biskupija-Crkvina aufmährischen Nekropolen, [w:] P. Kouřil (red.), Die frühmittelalterliche Elite bei den Völkern des östlichen Mitteleuropas mit einem speziellen Blick auf die grossmährische Problematik. Materialien der internationalen Fachkonferenz Mikulčice 15.-26.5.2004, Archeologický ústav AV ČR, Brno (Spisy Archeologického ústavu AV Čr Brno, 28), s.67-99.

Kouřil P. (2013), Der dritte Hortfund von Eisengegenständen aus dem slawischen Burgwall Staré Zámky in Brno-Lišseň, [w:] J. Kolenda, A. Mierzwiński, S. Moździoch, L. Żygadło (red.), Z badań nad kultura spoteczeństw pradziejowych i wczesnośredniowiecznych, Instytut Archeologii i Etnologii PAN, Wrocław, s. 599-615.

Kucypera P., Kurasinski T., Pudło P.(2011), Problem rozwoju jednolitych gtowic mieczowych między potowa IX a potowa XIII w., [w:] P. Kucypera, P. Pudło (red.), Cum Arma Per Aeva. Uzbrojenie indywidualne na przestrzeni dziejów, Wydawnictwo Adam Marszałek, Toruń.

Lüppes L. (2010), Gedanken zur spätmerowingingerzeitlichen Spathaaufhängung - eine $z u$ belegende und tragbare Rekonstruktion, „Archäologisches Korrespondenzblatt”, 40, s. $557-572$.

Lutovský M. (1994), Kolinský knižecí hrob: ad fontes, „Sborník Národního Muzea Praha”, 48.3-4, s. 37-76.

Die Macht des Silbers. Karolingische Schätze im Norden. Katalog zur Ausstellung im Archäologischen Museum Frankfurt [25. Februar bis 24. Juli 2005] und im Dom-Museum Hildesheim [3I. Juli bis II. Dezember 2005] in Zusammenarbeit mit dem Dänischen Nationalmuseum Kopenhagen (2005), E. Wamers (red.), Schnell\&Steiner, Regensburg.

Marek L. (2004), Wczesnośredniowieczne miecze z Europy Środkowej i Wschodniej. Dylematy archeologa i bronioznawcy, Wydawnictwo Uniwersytetu Wrocławskiego, Wrocław (Studia Archeologiczne, 36).

Menghin W. (1983), Das Schwert im Frühen Mittelalter. Chronologisch-typologische Untersuchgn zu Langschwertern aus germanischen Gräbern des 5. bis 7. Jahrhunderts n. Chr., Konrad Theiß Verlag, Stuttgart (Wissenschaftliche Beibände zum Anzeiger des Germanischen Nationalmuseums, I).

Paulsen P. (1953), Schwertortbänder der Wikingerzeit, W. Kohlhammer Verlag, Stuttgart.

Petersen J. (1919), De Norske Vikingesverd. En Typologisk-Kronologisk Studie Over Vikingetidens Vaaben, I Kommission Hos Jacob Dybwad, Kristiana.

Pieta K. (2017), Včasnostredoveké mocenské centrum Bojná - výskumy v rokoch 2007-2013, [w:] K. Pieta, Z. Robak (red.), Bojná 2. Nové výsledky výskumov včasnostredovekých hradisk, 2 výdanie, Archeologický ústav SAv, Nitra (Archeologica Slovaca Monographiae Fontes, 22), s. II-5I. 
Pieta K., Robak Z. (2017), The Early Medieval Hillfort Bojná-Valy, Slovakia, and its Defence System, „Acta Archaeologica Carpathica”, 52, s. 171-186.

Pieta K., Ruttkay A. (2007), Bojná - mocenské a christianizačné centrum Nitrianskeho kniežatstva. Predbežná správa, [w:] K. Pieta, A. Ruttkay, M. Ruttkay (red.), Bojná. Hospodarské a politické centrum Nitrianskeho kniežatstva, Archeologický ústav SAV, Nitra (Archeologica Slovaca Monographiae Studia, 9), s.2I-70.

Robak Z. (2013), Studia nad okuciami rzemieni w typie karolińskim. VIII-X wiek. I czesśc, Archeologický ústav SAV, Nitra (Archeologica Slovaca Monographiae Studia, I8).

Robak Z. (20I4), Studia nad okuciami rzemieni w typie karolińskim. VIII-X wiek. II część, Archeologický ústav SAV, Nitra (Archeologica Slovaca Monographiae Studia, 19).

Robak Z. (2017), The Origins and the Collapse of the Blatnica-Mikulčice Paradigm, „Slovenská archeológia”, 65.I, s. 99-162.

Robak Z. (2017-2018), Chronology and Periodisation of Imports of Carolingian Military Equipment in the Carpathian Basin between the Eighth and the Tenth Centuries, „Antaeus", 35-36, s. 327-344.

Robak Z. (2018a), The Sword and Sword-belt in Carolingian Times. The Warrior Burial 23 from Závada Reconsidered, „Študijné Zvesti Archeologického Ústavu SAV”, 64, s. $149-177$.

Robak Z. (2018b), Two Carolingian Strap-ends on Exhibition in Želiezovce (okr. Levice/sK), „Archäologisches Korrespondenzblatt”, 48.3, s. 417-435.

Robak Z. (2019), The Age of Migrating Ideas. A Short Contribution on Cruciform Decorations on Great Moravian Strap Fittings in the $9^{\text {th }}$ Century, [w:] L. Poláček, P. Kouřil (red.), Bewaffnung und Reiterausrüstung des 8. bis 1o. Jahrhunderts in Mitteleuropa. Waffenform und Waffenbeigaben bei den mährischen Slawen und in den Nachbarländern, Archeologický ústav AV ČR, Brno (Internationale Tagungen Mikulčice, 9), s. 453-460.

Robak Z. (202I), Wczesnośredniowieczne grodzisko Bojná-Valy na Stowacji. Nowe interpretacje, „Historia Slavorum Occidentis”, 28, s.36-64.

Ruttkay A. (1976), Waffen und Reiterausrüstung des g. bis zur ersten Hälfte des 14. Jahrhunderts in der Slowakei (II), „Slovenská archeológia”, 24, s. 245-395.

Ruttkay A. (1997), O velkomoravskom vojenstve s osobitným zretel'om na obdobie vlády Svätopluka, [w:] R. Marsina, A. Ruttkay (red.), Svätopluk 894-1994, Archeologický ústav SAV, Nitra, s. 175-189.

Staňa Č. (2006), Velkomoravská pohřebiště v Rajhradě a Rajhradicích. Katalog, Archeologický ústav AV ČR, Brno (Spisy Archeologického ústavu AV ČR Brno, 29).

Šolle M. (1966), Stará Kourim a projevy velkomoravské hmotné kultury v Čechách, Academia, Praha (Monumenta Archaeologica, I5).

Třeštík D. (1997), Počátky Přemyslovců. Lidové Noviny, Praha (Česká historie, I).

Třeštík D. (2009), Powstanie Wielkich Moraw. Morawianie, Czesi i Europa Środkowa w latach 79I-87I, Wydawnictwo Uniwersytetu Warszawskiego, Warszawa.

Ungerman Š. (2011a), Schwertgurte des 9. bis 1o. Jahrhunderts in West-und Mitteleuropa, [w:] J. Macháček, Š. Ungerman (red.), Frühgeschichtliche Zentralorte in Mitteleuropa. Internationale Konferenz und Kolleg der Alexander von Humboldt-Stiftung zum 50. Jahrestag des Beginns archäologischer Ausgrabungen in Pohansko bei Brreclav, 5.-9. Io. 2009, Habelt-Verlag, Bonn (Studien zur Archäologie Europas, I4), s. 575-608. 
Ungerman Š. (2011b), Tzv. blatnicko-mikulčický horizont a jeho vliv na chronologii raného středovèku, [w:] V. Turčan (red.), Karolinska kultúra a Slovensko, SNM-Archeologické muzeum, Bratislava (Zborník SNM, Archeologia, Supplementum, 4), s. 135-151.

Ungerman Š. (2017), Mečové pásy z 9.-Io. století v západni a středni Evropè (typologie, chronologie, provenience a symbolika), [w:] K. Pieta, Z. Robak (red.), Bojná 2. Nové výsledky výskumov vćasnostredovekých hradisk, 2 výdanie, Archeologický ústav SAV, Nitra (Archeologica Slovaca Monographiae Fontes, 22), s. 253-280.

Velká Morava a počátky křestáanství (2014), P. Kouřil (red.), Archeologický ústav AV Čr, Brno.

Vinski Z. (198I), O nalazima karolinških mačeva u Jugoslaviji, „Starohrvatska prosvieta”, III serija, II, s.9-54.

Wachowski K. (1986-1987), Merowingische und karolingische sporen auf dem Kontinent, „Zeitschrift für Archäologie des Mittelalters”, I4-15, s. 49-79.

Wachowski K. (1992), Kultura karolińska a Stowiańszczyzna Zachodnia, Wydawnictwo Uniwersytetu Wrocławskiego, Wrocław (Studia Archeologiczne, 23).

Wamers E. (198I), Ein karolingischer Prunkbeschlag aus dem Römisch-Germanischen Museum, Köln, „Zeitschrift für Archäologie des Mittelalters”, 9, s.9I-I28.

Wamers E. (1985), Insularer Metallschmuck in wikingerzeitlichen Gräbern Nordeuropas: Untersuchungen zur skandinavischen Westexpansion, Karl Wachholtz, Neumünster (Offa-Bücher, 56).

Wamers E. (1994), König im Grenzland. Neue Analyse des Bootkammergrabes von Haidaby, „Acta Archaeologica”, 65, s. I-56.

Wamers E. (2005), Aus Onkel Emilius'Schublade. Ein neuer kontinentaler Beschlag aus Lolland, [w:] H. Eilbracht, V. Brieske, B. Grodde (red.), Itinera Archaeologica. Vom Neolithikum bis in die frühe Neuzeit. Festschrift für Torsten Capelle, Verlag Marie Leidorf, Rahden/Westfalen (Internationale Archäologie, Studia Honoraria, 22), s.303-313.

Wamers E. (2008), Glaubesboten. „Aristokratische” Kunststile des 8. bis Io. Jahrhunderts n. Chr., [w:] G. Eggenstein, N. Börste, H.Zöller, E.Zahn-Biemüller (red.), Eine Welt in Bewegung: unterwegs zu Zentren des frühen Mittelalters. Begleitbuch der Gemeinschaftsausstellung, Deutscher Kunstverlag, München, s. 37-50.

Wamers E. (20II), Continental and Insular Metalwork, [w:] D. Skre (red.), Things from the Town. Artefacts and Inhabitants in Viking-Age Kaupang, Aarhus University Press, Árhus (Kaupang Excavation Project Publication Series, 3, Norske Oldfunn 24), s. 65-97.

\section{Summary}

The paper discusses the appearance of the Great Moravian warriors' swords and focuses on sets of strap and belt fittings used to fasten the swords. It also comments on other elements decorating sword scabbards used in Great Moravia in the $9^{\text {th }}$ and at the beginning of the $10^{\text {th }}$ century. The paper analyses the composition of the sword sets known from Great Moravia in the context of a wider typology and chronology of finds from European areas under the influence of the Carolingian culture between the beginning of the $9^{\text {th }}$ century and the $\mathrm{I}^{\text {st }}$ half of the $\mathrm{I}^{\mathrm{th}}$ century. 
An analysis of archaeological assemblages and loose finds of sword strap fittings from entire Europe (approx. 300 items) allows defining five basic types of Carolingian sword sets used in the late Carolingian times (beginning of the $9^{\text {th }}$ century $-\mathrm{I}^{\text {st }}$ half of the $10^{\text {th }}$ century) in the area under the Carolingian influences. Based on the analysis, it was also possible to determine the chronology and geographical scope of certain types of sword sets. Among the five identified types, four (I, II, IV, V) are known from the former Great Moravia territory. The only exception is type III, characteristic - so far - only for the north-western areas of the Carolingian Empire. The type I chronology covers the entire $9^{\text {th }}$ century, while all other types are generally dated back to the $2^{\text {nd }}$ half of the $9^{\text {th }}$ century and the beginning of the $\mathrm{IO}^{\text {th }}$ century. Detailed dating of finds can be clarified based on the ornamentation stylistics.

In nearly every case, swords found in Great Moravian burials bear traces of wood suggesting that the weapons were deposited in scabbards. Based on the analysis, we were able to determine that scabbards were made of hardwood. Detailed analysis of certain finds revealed traces of fabrics and leather and, exceptionally, also fine metal elements such as small rivets or fragments of sheet metal. Commonly, scabbards were also strengthened with additional straps that also decorated the items. Those straps could have been embossed with decorative patterns.

A scabbard chape from the Slovak Bojná-Valy hillfort is a unique find. The item was made of iron but its front side was plated with silver foil. Longer sides were inlaid with silver wire. So far, it is the only sword scabbard chape found in the Great Moravian context. The item has no contemporary analogies. It should be treated as an exceptional rarity, probably made at someone's special request.

Interestingly, in the Great Moravian context, there is no clear correlation between ornaments decorating pommels and cross-guards and the aesthetics of sets accompanying the swords - as if swords and fittings did not form a set. Moreover, swords with decorated pommels were usually not accompanied by sword sets but only by a strapend. It seems that in Great Moravia sword sets were unpopular until the $2^{\text {nd }}$ half of the $9^{\text {th }}$ century when the swords with decorated pommels (types B/H and $\mathrm{K}$ ) had been already outdated and types with undecorated pommels (type $\mathrm{N} / \mathrm{X}$ and $\mathrm{Y}$ ) became fashionable. Therefore, it seems that sword sets became popular among Great Moravian warriors in response to more modest sword decorations.

Keywords: Early Middle Ages, Carolingian culture, Great Moravia, sword, scabbard, strap fittings 